\title{
Position and structure of the Subtropical/Azores Front region from combined Lagrangian and remote sensing (IR/altimeter/SeaWiFS) measurements
}

\author{
Robin D. Pingree*, Carlos Garcia-Soto ${ }^{\dagger}$ and Bablu Sinha* \\ *Plymouth Marine Laboratory (NERG), Citadel Hill, Plymouth, PL1 2PB. \\ ${ }^{\dagger}$ Instituto Español de Oceanografía (MAPA), Apartado 240, 39080 Santander, Spain.
}

\begin{abstract}
The position and structure of the North Atlantic Subtropical Front is studied using Lagrangian flow tracks and remote sensing (AVHRR imagery: TOPEX/POSEIDON altimetry: SeaWiFS) in a broad region $\left(\sim 31^{\circ}\right.$ to $\left.\sim 36^{\circ} \mathrm{N}\right)$ of marked gradient of dynamic height (Azores Current) that extends from the Mid-Atlantic Ridge (MAR), near $\sim 40^{\circ} \mathrm{W}$, to the Eastern Boundary $\left(\sim 10^{\circ} \mathrm{W}\right)$. Drogued Argos buoy and ALACE tracks are superposed on infrared satellite images in the Subtropical Front region. Cold (cyclonic) structures, called 'Storms', and warm (anticyclonic) structures of 100-300 km in size can be found on the south side of the Subtropical Front outcrop, which has a temperature contrast of about $1^{\circ} \mathrm{C}$ that can be followed for $\sim 2500 \mathrm{~km}$ near $35^{\circ} \mathrm{N}$. Warmer water adjacent to the outcrop is flowing eastward (Azores Current) but some warm water is returned westward about $300 \mathrm{~km}$ to the south (southern Counterflow). Estimates of horizontal diffusion in a Storm $\left(D=2.2 \times 10^{2} \mathrm{~m}^{2} \mathrm{~s}^{-1}\right)$ and in the Subtropical Front region near $200 \mathrm{~m}$ depth $\left(D_{\mathrm{x}}=1.3 \times 10^{4} \mathrm{~m}^{2} \mathrm{~s}^{-1}, \mathrm{D}_{\mathrm{y}}=2.6 \times 10^{3} \mathrm{~m}^{2} \mathrm{~s}^{-1}\right)$ are made from the Lagrangian tracks. Altimeter and in situ measurements show that Storms track westwards. Storms are separated by about $510 \mathrm{~km}$ and move westward at $2.7 \mathrm{~km} \mathrm{~d}^{-1}$. Remote sensing reveals that some initial structures start evolving as far east as $23^{\circ} \mathrm{W}$ but are more organized near $29^{\circ} \mathrm{W}$ and therefore Storms are about 1 year old when they reach the MAR (having travelled a distance of $1000 \mathrm{~km}$ ). Structure and seasonality in SeaWiFS data in the region is examined.
\end{abstract}

\section{CONTENTS}

1. INTRODUCTION $\quad 770$

2. METHODS $r$

3. OBSERVATIONS AND RESULTS $\quad 772$

3.1. Background framework. Hydrographic structure of Subtropical Front and transport near $34^{\circ} \mathrm{N}$.

3.1.1. Mode Waters.

3.1.2. Dynamic height gradient. $\quad 772$

$\begin{array}{ll}\text { 3.1.3. Transport. } & 772 \\ \end{array}$

$\begin{array}{ll}\text { 3.1.4. Surface temperature. } & 774\end{array}$

$\begin{array}{lr}\text { 3.2. Eddy structure. } & 774\end{array}$

3.2.1. Storm 0 structure.

3.2.2. Warm and cold eddy structures.

3.3. Seasonal cycles of sea surface temperature in the Subtropical Region. 779

3.4. Diffusion in Storms.

$\begin{array}{ll}\text { 3.5. Subtropical Front position and structure. } & 782\end{array}$

$\begin{array}{ll}\text { 3.6. Ocean diffusion in the STF region. } & 784\end{array}$

3.7. Selected composite image showing Subtropical Front, cold cyclonic and warm

$\begin{array}{lr}\text { anticyclonic structures. } & 784 \\ \text { 3.8. Westward movement of structure. } & 786\end{array}$ $\begin{array}{ll}\text { 3.8.1. Storm generation region. } & 786\end{array}$

3.8.2. Summary of Storm positions $1994-1998$ near $33^{\circ} \mathrm{N} . \quad 788$

3.9. Seasonal cycle of surface chlorophyll $a$ and SeaWiFS data in the 789

4. CONCLUSIONS AND SUMMARY 790

5. REFERENCES $\quad 791$ 


\section{INTRODUGTION}

The deployment of 11 drogued buoys and five ALACE subsurface floats in a subtropical eddy called 'Storm 0' has allowed us to follow the westward progress of this eddy from $\sim 33^{\circ} \mathrm{W}$ to the Mid-Atlantic Ridge or MAR $\left(\sim 40^{\circ} \mathrm{W}\right)$ near $33^{\circ} \mathrm{N}$ over a period of $\sim 300$ days. Buoys leaving the eddy show the position of the Subtropical Front (STF) or Azores Current (AC). These Lagrangian observations can be used to interpret the sea surface structures observed by remote sensing. Earlier, Gould (1985) also tracked a single cyclonic eddy in the region for $\sim 200 \mathrm{~d}$ using three drogued buoys. In Pingree \& Sinha (1998), referred to subsequently as $P S$, it was shown using in situ direct measurements that Storms and associated anticyclones could exist as a regular train of eddies ( $\sim 3$ to 4 Storms when regularly formed) near $33^{\circ} \mathrm{N}$, on the south side of the Subtropical Front. The eddies moved westward at $3 \mathrm{~km} / \mathrm{d}$ with a mean separation of $520 \mathrm{~km}$ between successive low pressure regions in the west of the region $\left(\sim 27^{\circ} \mathrm{W}-40^{\circ} \mathrm{W}\right)$. Two Storms a year might pass a fixed point (e.g. Mooring 156) when regularly formed. It was also shown that these features were readily identified in altimeter data and that the surveyed Storm, called 'Storm 0', had a sea level depression signature of $42 \mathrm{~cm}$. Drogued buoy tracks were superposed on the altimeter sea surface elevation pattern to show alternate cyclonic and anticyclonic flow structure associated with low and high surface pressure cells near $33^{\circ} \mathrm{N}$. The hydrographic structure showed the eddies to be deeply penetrating with typical isotherm (isopycnal) displacements of $200 \mathrm{~m}$ from near surface $(\sim 200 \mathrm{~m})$ to the sea-floor $(\sim 3.8 \mathrm{~km})$. The altimeter surface elevation pattern mapped or mirrored changes in the deep ocean structure which showed a 600 times magnification for the isotherm (isopycnal) displacements. Successive cyclonic eddies, Storms 0, 1 and 2 (referred to here as $\mathrm{S}_{0}, \mathrm{~S}_{1}$ and $\mathrm{S}_{2}$ ), were surveyed or measured by hydrography and each was associated with a marked sea surface altimeter signature. The major westward propagating structures observed by altimeter remote sensing near $33^{\circ} \mathrm{N}$ were therefore interpreted as eddies rather than Rossby waves, though the regularly spaced eddies clearly have wavelike properties (Pingree, 2000). The eddy energy in the Subtropical Front region seen by the altimeter will be dominated by variability near semi-annual and shorter periods.

Here, we study the Subtropical Front region using infrared satellite imagery (AVHRR) and altimeter data in a broad region $\left(\sim 31^{\circ}\right.$ to $\left.\sim 36^{\circ} \mathrm{N}\right)$ of marked gradient of dynamic height (Azores Current) that extends from the Mid-Atlantic Ridge (MAR), near $\sim 40^{\circ} \mathrm{W}$ to the Eastern Boundary $\left(\sim 10^{\circ} \mathrm{W}\right)$. SeaWiFS data from January 1998 to February 1999 is appraised for structure and seasonality of surface chlorophyll $a$ in the Subtropical Front region and for Storm signatures. No distinction is made between the Subtropical Front (STF) or the Azores Front either being considered as the redistribution of mass that results in a thermal wind or the eastward flowing Azores Current. We superpose Lagrangian tracks on infrared satellite images in the Subtropical Front region and show that the signatures of eddies, the Subtropical Front and associated structures (e.g. $400-500 \mathrm{~km}$ scale) can sometimes be observed in the infrared imagery. The sea surface temperature (SST) of the Subtropical Front and adjacent regions is derived over an annual cycle from buoy temperature sensors. The thermal imagery identifies the Subtropical Front over a zonal scale of $\sim 3000 \mathrm{~km}$ and $\sim 500 \mathrm{~km}$ wavelike structure is clearly evident on the outcrop of the STF. Although eddies are less conspicuous (and Lagrangian tracks or altimeter data are generally necessary to confirm interpretations), we have been able to present in addition to Subtropical Front structure, the

Table 1. Number of days Argos buoy (with drogue depth in $m$ ) or ALACE float (at a mean pressure in dbar) remained in Storm 0. Rank (1) for buoy 25977 means that this was first buoy to leave the eddy.

\begin{tabular}{|c|c|c|c|c|c|}
\hline \multirow[b]{2}{*}{ Argos buoy no. } & \multirow[t]{2}{*}{$\begin{array}{c}\text { Deployment } \\
\text { year-day } 1995\end{array}$} & \multirow[t]{2}{*}{$\begin{array}{c}\text { Drogue } \\
\text { depth }(\mathrm{m})\end{array}$} & \multicolumn{2}{|c|}{$\begin{array}{l}\text { Days (rank) in } \\
\quad \text { Storm } 0\end{array}$} & \multirow[t]{2}{*}{ Comment } \\
\hline & & & & & \\
\hline 3899 & 302 & 200 & 143 & $(10)$ & \multirow{3}{*}{ shallow drogue (base of the mixed layer) } \\
\hline 5031 & 302 & 40 & 50 & $(2)$ & \\
\hline 5032 & 295 & 360 & 190 & $(12)$ & \\
\hline 25682 & 297 & 100 & 72 & $(4)$ & \multirow[t]{3}{*}{ drogue loss } \\
\hline 25683 & 297 & 100 & 88 & (7) & \\
\hline 25684 & 295 & 100 & 134 & (9) & \\
\hline 25685 & 292 & 100 & 73 & $(5)$ & \multirow{3}{*}{$\begin{array}{l}\text { deployed in region of maximum flow } \\
\text { stopped transmitting for } 157 \text { days }\end{array}$} \\
\hline 25686 & 297 & 200 & 198 & $(13)$ & \\
\hline 25687 & 295 & 200 & 200 & $(14)$ & \\
\hline 25977 & 292 & 200 & 38 & $(1)$ & \multirow[t]{2}{*}{ deployed in region of maximum flow } \\
\hline ALACE float no. & & $\begin{array}{c}\text { Pressure } \\
\text { (dbar) }\end{array}$ & & & \\
\hline 25972 & 297 & 195 & 208 & $(15)$ & \multirow{5}{*}{$\begin{array}{l}\text { deepest Lagrangian measurement } \\
\text { deployed in region of maximum flow }\end{array}$} \\
\hline 25973 & 297 & 780 & 80 & $(6)$ & \\
\hline 25974 & 292 & 220 & 65 & $(3)$ & \\
\hline 25975 & 297 & 475 & 110 & $(8)$ & \\
\hline 25976 & 302 & 760 & 176 & $(11)$ & \\
\hline Argos buoy no. & $\begin{array}{c}\text { Deployment } \\
\text { year-day } 1996\end{array}$ & $\begin{array}{l}\text { Drogue } \\
\text { depth }(\mathrm{m})\end{array}$ & \multirow{2}{*}{\multicolumn{2}{|c|}{77}} & \\
\hline 1811 & 156 & 200 & & & deployed from HMS 'Hecla' in June 1996 \\
\hline
\end{tabular}


Table 2. Summary of characteristics of the satellite data (date, overhead time, NOAA number, orbit and identification code at Dundee University) and Argos buoy and ALACE float ( $A L)$ data (with track period in year-days, identification code and depth ( $m$ ) of the drogued buoys and mean pressure (dbar) for the ALACE) used in the Figures.

\begin{tabular}{|c|c|c|c|c|c|c|}
\hline Date & Time GMT & $\begin{array}{c}\text { Satellite Data } \\
\text { Number }\end{array}$ & Orbit & ID & $\begin{array}{l}\text { Year-day } \\
1995,1996\end{array}$ & $\begin{array}{l}\text { angian Data } \\
\text { Buoy (Drogue } \\
\text { Depth, m) AL/ALACE } \\
\text { (Pressure, dbar) }\end{array}$ \\
\hline \multicolumn{7}{|c|}{ Figure 2 (continuation of Figure 10B) } \\
\hline $\begin{array}{l}4.06 .96 \\
\text { Figure 5A }\end{array}$ & 1434 & NOAA-14 & 7367 & $1757 / 07$ & & \\
\hline 8.12 .95 & 1506 & NOAA-14 & 4842 & $1663 / 10$ & $\begin{array}{l}320-365 \\
336-11\end{array}$ & $\begin{array}{l}25682(100), 25683 \\
(100), 25684(100), \\
25685(100), 25687 \\
(200), 3899(200), 5032 \\
(360) \\
25977(200) \\
5031(40)\end{array}$ \\
\hline \multicolumn{7}{|l|}{ Figure $5 \mathrm{~B}$} \\
\hline 01.02 .96 & 1514 & NOAA-14 & 5618 & $1629 / 08$ & $22-43$ & $\begin{array}{l}25682(100), 25684 \\
(100), 25687(200), 3899 \\
(200), 5032(360)\end{array}$ \\
\hline \multicolumn{7}{|l|}{ Figure $6 \mathrm{~A}$} \\
\hline 09.03 .96 & 1515 & NOAA-14 & 6140 & $1711 / 09$ & $58-79$ & $\begin{array}{l}25684(100), 25687 \\
(200), 3899(200), 5032 \\
(360)\end{array}$ \\
\hline \multicolumn{7}{|l|}{ Figure $6 \mathrm{~B}$} \\
\hline 05.04 .96 & 1524 & NOAA-14 & 6521 & $1726 / 07$ & $86-107$ & $\begin{array}{l}25684(100), 25687 \\
(200), 5032(360)\end{array}$ \\
\hline \multicolumn{7}{|l|}{ Figure 7} \\
\hline 25.10 .92 & 1645 & NOAA-11 & 21056 & $1226 / 11$ & & \\
\hline $\begin{array}{l}27.10 .92 \\
\text { Figure } 10 \mathrm{~A}\end{array}$ & \multicolumn{5}{|c|}{ Figure $10 \mathrm{~A}$} & \\
\hline 01.02 .96 & 1514 & NOAA-14 & 5618 & $1692 / 08$ & $365-50$ & $25977(200)$ \\
\hline $\begin{array}{l}09.02 .96 \\
\text { Figure 10B }\end{array}$ & 0351 & NOAA-14 & 5724 & $1696 / 05$ & $332-87$ & $\mathrm{AL} / 25974(215)$ \\
\hline 08.06 .96 & 1533 & NOAA-14 & 7424 & $1759 / 09$ & $161-205$ & $25686(200)$ \\
\hline 09.06 .96 & 0831 & NOAA-12 & 26335 & $1759 / 1$ & 132-183 & $25687(200)$ \\
\hline 10.06 .96 & 0810 & NOAA-12 & 26349 & $1760 / 06$ & $\begin{array}{l}160-190 \\
147-167 \\
140-172 \\
133-173\end{array}$ & $\begin{array}{l}5030(200) \\
\mathrm{AL} / 25974(190) \\
\mathrm{AL} / 25975(435) \\
\mathrm{AL} / 25976(750)\end{array}$ \\
\hline \multicolumn{7}{|l|}{ Figure 12} \\
\hline 04.02 .97 & 0747 & NOAA-12 & 29747 & $1899 / 06$ & & \\
\hline 05.02 .97 & 1510 & NOAA-14 & 10838 & $1900 / 03$ & & \\
\hline 10.02 .97 & 0715 & NOAA-12 & 29832 & $1902 / 14$ & & \\
\hline \multicolumn{7}{|l|}{ Figure 14} \\
\hline 22.11 .96 & 0348 & NOAA-14 & 9773 & $1853 / 03$ & & \\
\hline 23.11 .96 & 0338 & NOAA-14 & 9787 & $1853 / 11$ & & \\
\hline
\end{tabular}

thermal signatures of the initial structure of the next two Storms passing westward near $33^{\circ} \mathrm{N}, \mathrm{S}_{3}$ and $\mathrm{S}_{4}$, in relation to the thermal Subtropical Front outcrop near $35^{\circ} \mathrm{N}$ and follow their westward progress using altimetry. The easterly thermal structures (i.e. $\mathrm{S}_{4}$ ), seen in the infrared imagery, show that Storms can start forming, as plumes of cold water from the north, as far east as $23^{\circ} \mathrm{W}$. The mean position and zonal extent of the Subtropical Front outcrop or Azores Current is not so readily derived from altimeter data (see Le Grand, 1998) since a reference state is removed to determine the sea level anomaly. However, the altimeter sea level anomalies identify individual eddies much more clearly and these are seen to be tracking westward in the warmer water south of the thermal STF outcrop $\left(\sim 35^{\circ} \mathrm{N}\right)$ identified in the infrared imagery. Some of these cyclonic eddies intensify as they travel westward near $33^{\circ} \mathrm{N}$ by merging with other eddies, others decay, elongate and split or are absorbed by other eddies or the AC and do not reach the MAR.

\section{METHODS}

In all, ten drogued Argos buoys and five ALACE floats tracked Storm 0 for varying degrees of time (see Table 1) from the initial RRS 'Charles Darwin' survey position near $33^{\circ} \mathrm{W}$ in October 1995 to near the Mid-Atlantic Ridge (MAR). A further Argos buoy (1811) deployed, from HMS 'Hecla' continued tracking Storm 0, over the MAR, extending the in situ tracking period from October 1995 to August 1996 ( 300 days). Lagrangian structures 
in the eddy and subsequently in the STF region are appraised in conjunction with remote sensing data. The satellite thermal infrared (IR) structure of the Subtropical Front region was examined using band $4(11.5-12.5 \mu \mathrm{m})$ data from the Advanced Very High Resolution Radiometer (AVHRR) onboard the NOAA-12 and NOAA-14 satellites. The data were processed following standard AVHRR image analysis techniques (e.g. Holligan et al., 1989). The actual satellite data used are listed in Table 2 as a reference source as it has not been possible to show all features of interest with a single brightness contrast and relevant cloud free images have not be found with which to make a cloud free composite image. Because of this, it has been found necessary to draw the position of the thermal STF (or temperature contrast structures with cooler water to the north, appraised from the images listed in Table 2) on three of the figures for a clearer presentation of the STF position in relation to the distribution of subpolar and subtropical Mode Waters, the Lagrangian tracks in Storm 0 and the oceanic tracks in the STF region. Tracks from 11 drogued Argos buoys and three ALACE floats (Davis et al., 1992) were superposed on the AVHRR imagery. Table 2 shows the track period (in year-days), the depth of the drogue for the ARGOS buoys and the mean pressure of the ALACE floats. The individual buoys and ALACEs are referenced by their identification numbers and these same numbers were used in related Lagrangian studies (e.g. Pingree et al., 1996). The droguing was careful (i.e. drogues had to stay attached for long periods, $>1$ year) and effective (Pingree, 1997). The drogue acceleration difference test of Pingree (1993) was applied to the data recorded for each of the 11 drogued Argos buoys to determine whether the drogue was still attached as drogue attachment sensors can be unreliable. The surface temperature sensors on the Argos buoys were calibrated on deployment against in situ sea surface temperature (SST) measurements. Temperature data were also used from buoys that lost their drogues in a few instances. Hydrographic data are taken from RRS 'Charles Darwin' CD66, GD83 and CD97 cruises in the region and a North Atlantic crossing near $33^{\circ} \mathrm{N}$ completed by HMS 'Hecla'. Cruise reports are listed in Pingree (1997). Altimeter data and products were received and used from AVISO (1996) and from the CLS website/ftpsite. Data processing procedures and displays for the latter are described in Le Traon et al. (1998).

\section{OBSERVATIONS AND RESULTS}

\subsection{Background framework. Hydrographic structure of Subtropical Front and transport near $34^{\circ} \mathcal{N}$}

3.1.1. Mode Waters. The position of the Subtropical Front (STF) or Azores Current (AC) results (see New, 1997) from the production of a subtropical mode water $\left(\sigma_{\mathrm{o}} \sim 26.45 \mathrm{~kg} \mathrm{~m}^{-3}, \sim\right.$ Sargasso Sea Water properties $)$ and a more northern mode water $\left(\sigma_{\mathrm{o}} \sim 27.1 \mathrm{~kg} \mathrm{~m}^{-3}, \sim\right.$ Eastern North Atlantic Central Water (ENACW), Pollard et al., 1996). Remarkably, the maximum thickness for the winter Subtropical Mode Water (STMW) with $26.4<\sigma_{\mathrm{o}}<26.6 \mathrm{~kg} \mathrm{~m}^{-3}$ lies close to (and above) the region of minimum winter thickness for water in the $27.0<\sigma_{\mathrm{o}}<27.2 \mathrm{~kg} \mathrm{~m}^{-3}$ density band, near $55^{\circ} \mathrm{W}, 37^{\circ} \mathrm{N}$
(WOA94 data). The winter thickness of these two mode waters (Figure 1; Levitus, 1982) changes in the STF/AC region and this region (usually given as a subduction zone) was considered as a barrier to vented subduction from the north in Pingree et al. (1996) and Pingree (1997), with east-west flow near the subtropical boundary or recirculating flow rather than direct southward flow across the region. The maximum winter thickness of ENACW is near $\sim 46^{\circ} \mathrm{N} 16^{\circ} \mathrm{W}$ (WOA94 data). The two mode waters lie alongside each other at the STF/AC boundary with the northern water at a depth near $500 \mathrm{~m}$ and the subtropical water, though partially modified by mixing, in the upper $200 \mathrm{~m}$ (see for example, Rios et al., 1992).

3.1.2. Dynamic height gradient. The distribution of Mode Waters (Figure 1) results in a region of marked gradient of dynamic height (a scalar, derived from both north and east components) at the sea surface (relative to 2000 dbar) that extends from the Mid-Atlantic Ridge (MAR) $\sim 40^{\circ} \mathrm{W}$ to east of Madeira $\left(\sim 15^{\circ} \mathrm{W}\right)$ near a latitude of $34^{\circ} \mathrm{N}$ and identifies the mean position of the Subtropical Front (Figure 2; Levitus, 1982). The maximum dynamic height gradient relates to the maximum surface geostrophic current or surface AC. For simplicity, we have converted dynamic height into water height or sea surface height so that the dynamic height gradient is expressed as its equivalent sea surface slope without dimensions. Using the higher resolution WOA94 data (and the average of four seasons) increases the gradient values by about $40 \%$ in the region of maximum values near $34^{\circ} \mathrm{N}$ with maximum values just $>35 \times 10^{-8}$ near $32^{\circ} \mathrm{W}$. Although the axis of the maximum dynamic height gradient is near zonal or aligned east/west, the dynamic height contours themselves slope at about $15^{\circ}$ to a fixed latitude $\left(\sim 34^{\circ} \mathrm{N}\right)$, with the 1.70 dyn $\mathrm{m}$ contour passing near $30^{\circ} \mathrm{W}$ and $1.60 \mathrm{dyn} \mathrm{m}$ contour near $15^{\circ} \mathrm{W}$. Satellite (AVHRR) infrared images are appraised for the position of Subtropical Front and structure in this region of maximum sea surface slope. The dynamic height gradient (using WOA94 historical data base, see for example, Levitus \& Boyer (1994)) although marked shows little clear variation in position or intensity seasonally (Le Traon \& De Mey, 1994).

3.1.3. Transport. Transport values (using WOA94 data) at a mid position $\left(\sim 30.5^{\circ} \mathrm{W}\right)$ for a meridional section across the Azores Current from $30.5^{\circ} \mathrm{N}-36.5^{\circ} \mathrm{N}$ were $7.1 \mathrm{~Sv}$ (reference level $1000 \mathrm{dbar}$ and using the mean of the seasonal values) and $10.0 \mathrm{~Sv}$ (2000 dbar reference level; dynamic height difference $16 \mathrm{dyn} \mathrm{cm}$ ). These values are comparable but rather smaller ( $5.5 \mathrm{~Sv}$ to $800 \mathrm{dbar}$ ) than previous values (e.g. $\sim 8 \mathrm{~Sv}$ to $800 \mathrm{~m}$, Klein \& Siedler, 1989). At $24.5^{\circ} \mathrm{W}$, the values were $5.1 \mathrm{~Sv}$ (reference level $800 \mathrm{dbar}$ ) and $11.0 \mathrm{~Sv}$ (reference level $2000 \mathrm{dbar}$ ); at $20.5^{\circ} \mathrm{W}$, the values were $4.0 \mathrm{~Sv}$ (reference level $800 \mathrm{dbar}$ ) and $6.7 \mathrm{~Sv}$ (reference level $2000 \mathrm{dbar}$; dynamic height difference 12 dyn $\mathrm{cm}$ ). The values become smaller in the east as the flow is turned south. The instantaneous Azores Current can have a significant transport $(\sim 26 \mathrm{~Sv}$, Pingree, 1997; 16-18 Sv, Tychensky et al., 1998) in this region but the total transport across the region may be much reduced by the adjacent Counterflows that may be 


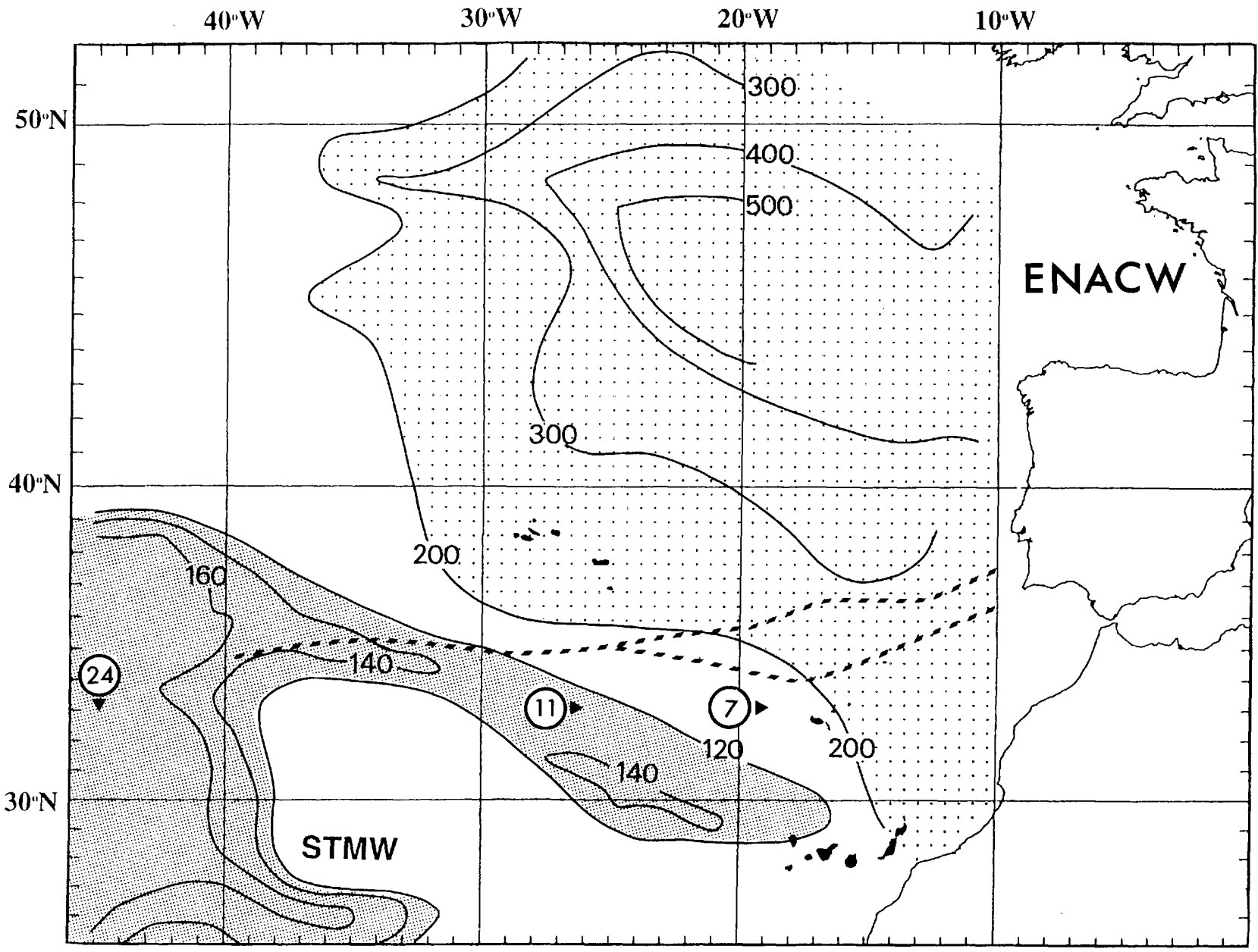

Figure 1. Winter thickness (m) of Eastern North Atlantic Central Water (ENACW) Mode Water with $27.0<\sigma_{\mathrm{o}}<27.2 \mathrm{~kg} \mathrm{~m}^{-3}$, with maximum winter thickness near $\sim 46^{\circ} \mathrm{N} 16^{\circ} \mathrm{W}$ (WOA94 data) and Subtropical Mode Water (STMW) with $26.4<\sigma_{\mathrm{o}}<26.6 \mathrm{~kg} \mathrm{~m}^{-3}$ (which contains Sargasso Sea Water $\left(\sim 18^{\circ} \mathrm{C}\right.$ ) with $\left.\sigma_{\mathrm{o}} \sim 26.45 \mathrm{~kg} \mathrm{~m}^{-3}\right)$. The STMW has a maximum winter thickness $(240 \mathrm{~m})$ in the Western Basin at $\sim 36^{\circ} \mathrm{N} 52^{\circ} \mathrm{W}$, near the position of minimum thickness $(80 \mathrm{~m})$ of water with $27.0<\sigma_{\mathrm{o}}<27.2 \mathrm{~kg} \mathrm{~m}^{-3}$, located near $37^{\circ} \mathrm{N}, 55^{\circ} \mathrm{W}$. The dashed lines represent mean positions of the Subtropical Front derived from the infrared imagery (see text for details). Ringed values are transport (in Sv, reference level $2000 \mathrm{dbar}$ ) associated with the STF (see text for details).

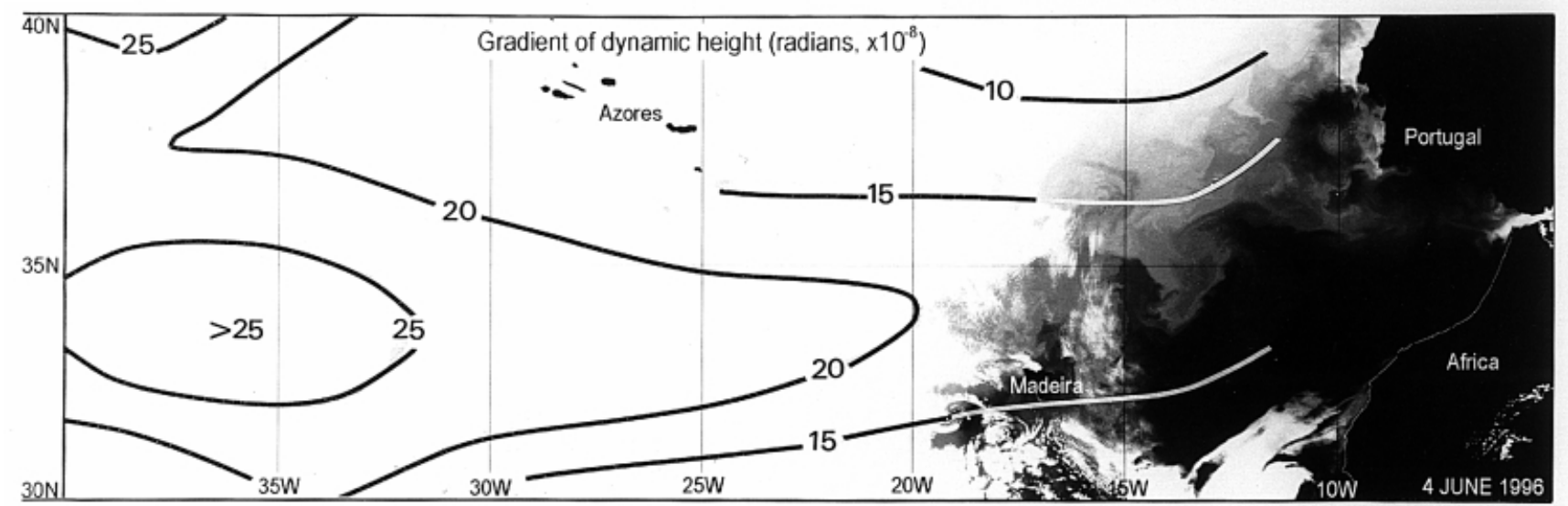

Figure 2. Distribution of gradient of dynamic height (expressed as equivalent sea surface slope $\times 10^{-8}$; mean annual value relative to 2000 dbar) in the Eastern Basin of the North Atlantic. The satellite (AVHRR) infrared image of 4.6.96 is superposed in the east. Temperature calibrations (see Figure 8) give a change of about $1{ }^{\circ} \mathrm{C}$ (the cooler being near $18.4^{\circ} \mathrm{C}$ ) across the STF near $35^{\circ} \mathrm{N}, 14^{\circ} \mathrm{W}$. Further June images covering the full region are illustrated in Figure 10b. The completely white features are clouds; dark regions show warm water. The sea level anomaly of the cyclonic structure near $14^{\circ} \mathrm{W} 35^{\circ} \mathrm{N}$ in the frontal region is evident in Figure 16. 
present. No clear evidence was found for westward counterflows in the seasonal historical data (WOA94) at these sections (cf. Käse \& Krauss, 1996, their figure 10.21a) but high-resolution ocean circulation models that resolve the AC show some evidence for the presence of adjacent counterflows (New et al., 2000). Neither was there clear evidence for the AC branches (see for example, Siedler \& Onken (1996), their figure 11.6) based on annual averaged data. Buoy tracks do, however, tend to show a branch to the south near $20^{\circ} \mathrm{W}$ but this may be the eastward extension of the AC itself turning to the south.

For an overall baseline reference of the transport for the Azores Current or STF for the future monitoring of climate change we use the carefully calibrated CTD data from HMS 'Hecla'. With a reference level of $3000 \mathrm{dbar}$, the transport between CTD 7018 at $50.0^{\circ} \mathrm{W}, 32.5^{\circ} \mathrm{N}$ (1.6.96) and CTD 7025 at $20.0^{\circ} \mathrm{W}, 35.5^{\circ} \mathrm{N}$ (6.6.96) was $28 \mathrm{~Sv}$. Transport values between CTDs were corrected for eddy transports by making a transport correction based on the altimeter sea level anomaly difference between stations (see $P S$ ). It turned out that the sea level anomaly difference between CTD 7018 and CTD 7025 was less than $2 \mathrm{~cm}$ and the correction in this case was less than 2 Sv. With a 2000 dbar reference level, the transport was $24 \mathrm{~Sv}$ and the dynamic height difference was $41 \mathrm{dyn} \mathrm{cm}$. The transport values given (with a reference level of $2000 \mathrm{dbar})$ for the STF region are summarized in Figure 1.

3.1.4. Surface temperature. This study of the Subtropical Front and associated structure has focused on infrared images with structure in the region of maximum dynamic height gradient or just to the north since a near zonal region of mean maximum temperature contrast at a fixed latitude is not defined. For example, maps of mean sea surface $(\sim 50 \mathrm{~m})$ temperature do not show an increased temperature gradient between $30^{\circ}-40^{\circ} \mathrm{N}$, even for the winter (March) period but at $200 \mathrm{~m}$ depth a temperature front near $33.5^{\circ} \mathrm{N}\left(20-30^{\circ} \mathrm{W}\right.$, with mean temperature $15.9^{\circ} \mathrm{C}$ ) is evident. Seatruth can show a winter surface temperature contrast $\left(17-18^{\circ} \mathrm{C}\right)$ in the region of interest near $34^{\circ}-35^{\circ} \mathrm{N}$ (Fernández \& Pingree, 1996). Single images show increased temperature contrasts, but over a wide range of latitudes (see monthly summary of thermal months for the period 1980-1988 in SATMER (1983 to 1988). The image of 10 March 1984 (SATMER, 1984; Kielmann \& Käse, 1987) suggests a maximum temperature contrast near $38^{\circ}-39^{\circ} \mathrm{N}$ (in the region east of the Azores) with further warm and cold features of interest between $35^{\circ}-37^{\circ} \mathrm{N}$. Some mean temperature gradients in the region based on sea surface temperature satellite data are given by Hernández-Guerra \& Nykjaer (1997). A reference atlas of monthly (from May 1993 to April 1996) mean sea surface temperature of the north-east Atlantic derived from infrared remote sensing (AVHRR) has been given by Oliveira et al. (1996). The Subtropical Front studied here (near $34^{\circ} \mathrm{N}$, or region of maximum dynamic height gradient) has a winter (March) temperature of $\sim 18^{\circ} \mathrm{C}$ towards the west $\left(\sim 30^{\circ} \mathrm{W}\right)$ of the region and is $\sim 17^{\circ} \mathrm{C}$ in the east $\left(\sim 10^{\circ} \mathrm{W}\right)$; the winter (March) salinity is near 36.5-36.7 psu. Cruise data shows that the $\sigma_{\mathrm{t}}=26.5$ isopycnal in the Subtropical Front (STF) is fresh on the north side of the Azores Current and salty on the south side; the mean temperature on a central streamline of the Azores Current (AC) on this isopycnal is close to $17.4^{\circ} \mathrm{C}$.

The mean surface position of the thermal STF based on the three infrared images studied here is drawn on Figure 1. A further line (overlapping in the west) but to the north in the east shows a mean position based on three images in March (1984, 1992, 1997). The overall position for the remote sensing sea surface thermal boundary lies close to the region of maximum gradient of dynamic height showing that the position and structure of the infrared frontal region examined in this paper relates to the dynamic STF boundary or AC. In fact, the mean frontal position based on the selected images lies just to the north of $34^{\circ} \mathrm{N}$, reflecting the surface outcrop of the Subtropical Front structure in the region. The dynamic height gradient is an integrated property and so also reflects the inclination of the structure or outcrop at depth. Thus the maximum dynamic height gradient will lie to the south of the STF outcrop. Since the AC is typically about $100 \mathrm{~km}$ wide, cyclonic eddies travelling west near $33^{\circ} \mathrm{N}$ will be moving through surface water of subtropical origin.

\subsection{Eddy structure}

3.2.1. Storm 0 structure. The eddy, Storm 0, was characterized as a near-surface cold-core anomaly (Pingree et al., 1996) but there was no clear sea surface temperature anomaly in October 1995 when the initial hydrographic survey (RRS ‘Charles Darwin' Cruise, CD97) was undertaken near $32.5^{\circ} \mathrm{N} 33^{\circ} \mathrm{W}$. The initial shape of the eddy from the buoy data was elliptical with a central ratio of minor to major axes of $\sim 0.7$. The central orbits were cyclonic with period $\sim 13$ days. The ellipse itself also rotated cyclonically at a rate of $\sim 1^{\circ}$ per day. Of the ten Argos buoys and five ALACE deployed initially in October, two buoys (buoy 25687 drogued at $200 \mathrm{~m}$ depth and buoy 5032 drogued at $360 \mathrm{~m}$ depth) gave continuous tracks and two ALACE (ALACE 25972 (195 dbar) and ALACE 25976 (760 dbar)) gave positions within the eddy until 5 April (i.e. remained with the eddy for more than 160 days). The fact that ALACE 25976 at a mean pressure of $\sim 760 \mathrm{dbar}$ (mean temperature $\sim 9.3^{\circ} \mathrm{C}$ ) moved westward in the eddy shows that the structure penetrates to depth. Indeed, the $9.3^{\circ} \mathrm{C}$ isotherm is found at a mean pressure (depth) of $\sim 960 \mathrm{dbar}(950 \mathrm{~m})$ in the region (PS, HMS 'Hecla' data) so the ALACE float was in a cold anomaly where the isotherms were raised by about $200 \mathrm{~m}$. Over the same period, the mean temperature of ALACE 25972, at the shallower level ( 195 dbar), was $15.2^{\circ} \mathrm{C}$. This isotherm was at a mean pressure of $430 \mathrm{dbar}$ so the shallower float also moved in a region where the isotherms were raised by a similar amount $\sim 230 \mathrm{~m}$. Buoys 25687 and 5032 travelled with the eddy for $\sim 200 \mathrm{~d}$ and $190 \mathrm{~d}$ respectively moving $\sim 500 \mathrm{~km}$ westwards near a latitude of $\sim 32.5^{\circ} \mathrm{N}$ at a mean speed of $\sim 2.5 \mathrm{~km} \mathrm{~d}^{-1}$. ALACE 25972 also remained in the eddy for 200 days. The drogued buoy tracks in the eddy showing the general coverage of data in the region are summarized in Figure 3. The initial rotation of the elliptical structure is clearly evident in the position data. The magnitude of the associated Lagrangian velocities (with components u-east, v-north) is obtained by plotting 


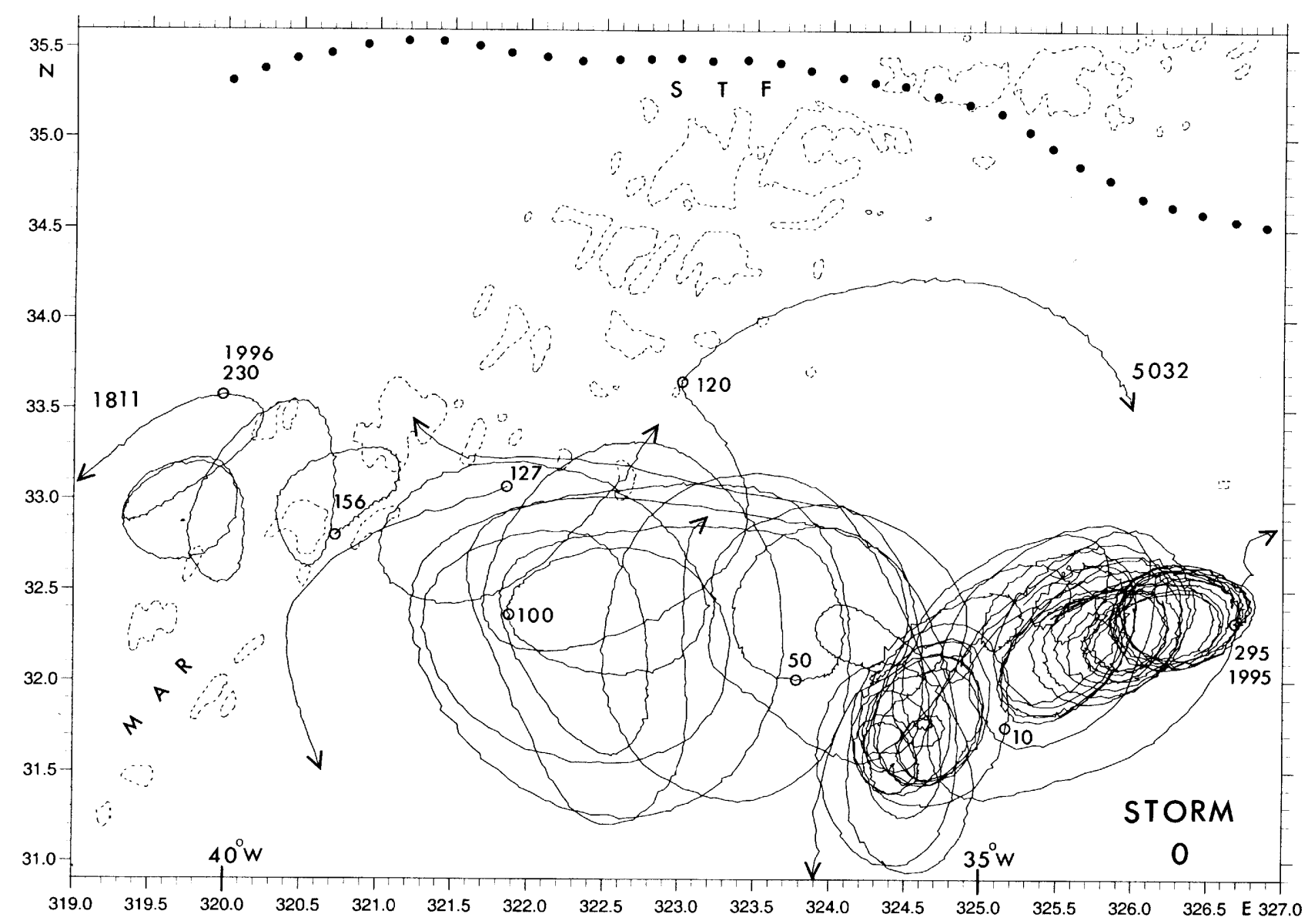

Figure 3. Tracks (raw data) of eight buoys deployed in the central region of Storm 0 in October 1995 and further track of buoy 1811 (labelled) deployed from HMS 'Hecla' in June 1996 (year-day 156). The tracks extend from year-day 295 (1995) to year-day 233 (1996). Some annotated year-days (marked with circles) are given. Overall, the tracks cover 303 days and extend over a distance of $700 \mathrm{~km}$. Tracks leaving the eddy are shown with an arrow. One track (buoy 5032, labelled) is extended for a further 15 days to show the position of the south part of the eastward Azores Current near year-days 120-135 (1996). The STF (dotted) is an approximate averaged position for the Subtropical Front based on contrast structures seen in infrared images covering the period December 1995 to June 1996 (see Table 2). The MAR is depicted by $2000 \mathrm{~m}$ depth contour.

all the buoy velocities in the $\mathrm{u}-\mathrm{v}$ plane (Figure 4 ). The distribution of swirl velocity against radius is given in $P S$ (their figure 7). The orbital velocities increase from near zero in the eddy centre to about $40 \mathrm{~cm} \mathrm{~s}^{-1}$ at a radius of about $80 \mathrm{~km}$ but some maximum speeds reach $\sim 70 \mathrm{~cm} \mathrm{~s}^{-1}$. For the near central region, consecutive 15 day plots in the velocity plane (not shown) confirmed a mean rotation of structure of one degree a day.

3.2.2. Warm and cold eddy structures. The movement of the Argos buoys in the eddy with respect to the thermal imagery is shown in Figures $5 \& 6$ for the period from December (1995) to April (1996). The Figures show most of the available (cloud free) satellite imagery during the 200 day period the Argos buoys were tracking the eddy. The temperature sensors on the buoys showed that the subtropical water to the south tends to be $\sim 0.7^{\circ} \mathrm{C}$ warmer than the eddy surface temperature (see later section 3.3.). If this warmer water is drawn around or alongside the eddy, then exterior structure may be highlighted.

In early December 1995, the Subtropical Front is near $36^{\circ} \mathrm{N}$ in the west and near $34^{\circ} \mathrm{N}$ in the east passing $35^{\circ} \mathrm{N}$ at a longitude of $35^{\circ} \mathrm{W}$ (Figure 5A). The surface expression of the subtropical eddy (Storm 0 , or $\mathrm{S}_{0}$ ) is an elliptical cool patch with a slightly warmer central region $\left(\sim 35^{\circ} \mathrm{W}\right)$ near the innermost buoys which are moving cyclonically. Buoys leaving this region reach the Subtropical Front (Azores Current) near $34^{\circ} \mathrm{N}$ but then tend to move clockwise around the warm water region $(\mathrm{W})$ which is an anticyclonic region of negative vorticity (track of buoy 5031) separating Storm 0 from Storm 1 (developing near $29^{\circ} \mathrm{W}$, altimeter data). Seven out of the ten drogued buoys deployed in the eddy left the eddy to the north or north-east and then moved eastward in the warm STF/AC flow or were turned anticyclonically in a warm water cell. This implies that some eastward flowing $\mathrm{AC}$ water passes south around the cyclonic eddy and that the exterior region of the eddy is within the influence of the STF or eastward moving water.

At the start of February 1996, the eddy signature is a cool region and the centre estimated from the drogued buoy tracks has moved to $35.5^{\circ} \mathrm{W}$ (Figure $5 \mathrm{~B}$ ). A warm water region $(\mathrm{W})$ is still evident to the east of the cyclonic eddy. The Subtropical Front itself has developed a pattern of 


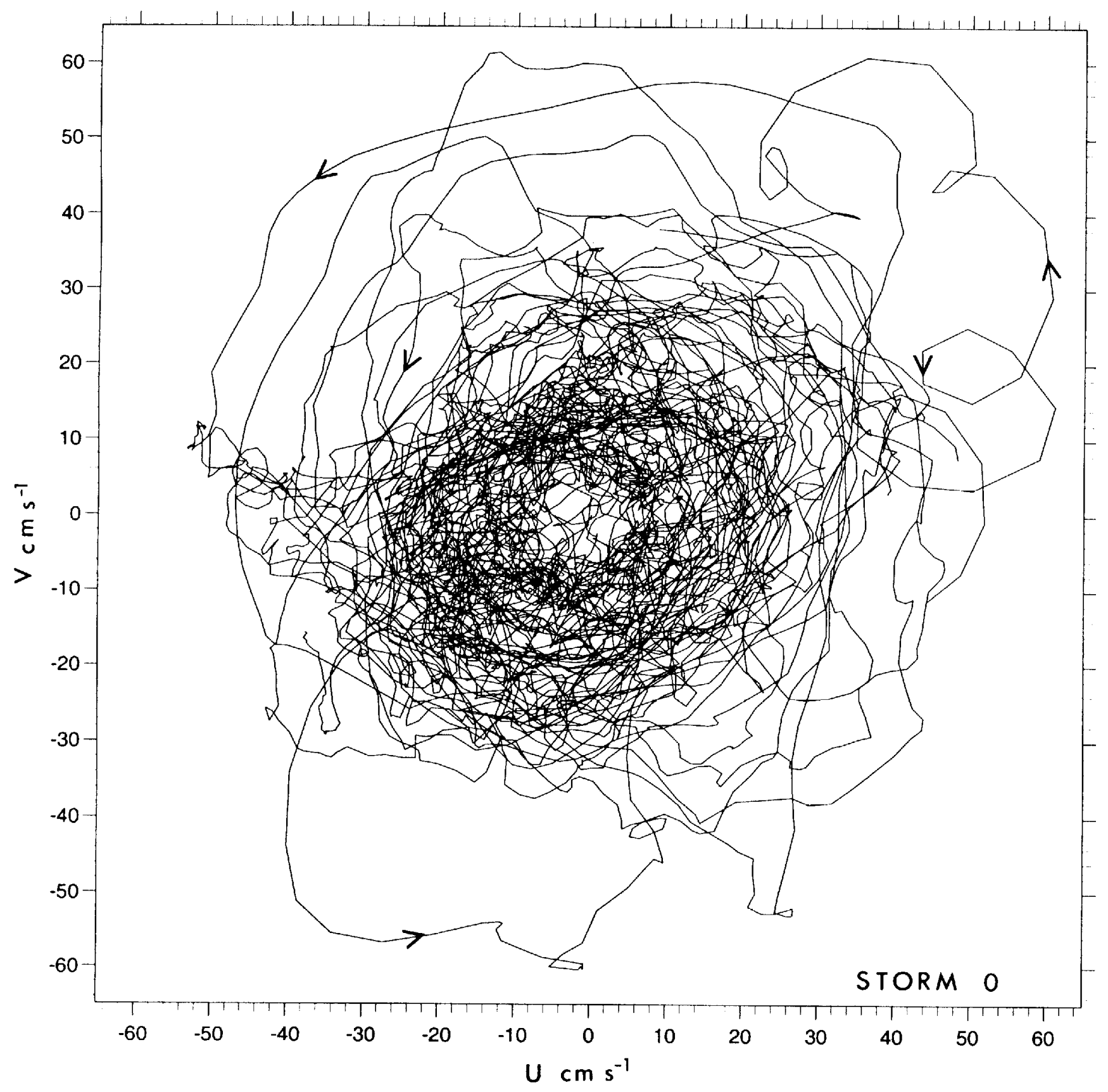

Figure 4. East and north components of velocity (derived from $12 \mathrm{~h}$ averaging of position data) of all buoys in Storm 0 (representing 2.9 buoy-years of eddy velocity data). The apparent centre is displaced as buoys are moving westward with the eddy. Eddy rotation sense is clockwise and clockwise inertial motion is also evident.

alternate warm $(\mathrm{W})$ and cold structures $(\mathrm{C})$ near $34^{\circ}-35^{\circ} \mathrm{N}$ and the inferred sense of surface water movement is indicated with curved broken arrows. The cool patch or cell protruding south from the STF near $34^{\circ} \mathrm{W}$ tends to merge with the cooler regions of the sea surface temperature of Storm 0, and this association with the STF can be a characteristic Storm signature. Altimeter structures show that Storms can split and an elongation of the structure to the north-east followed by a major splitting occurred in January 1996, though no drogued buoys were drawn into the associated cold water cell (or the altimeter low pressure cell) that was found near $34^{\circ} \mathrm{W}\left(34.5^{\circ} \mathrm{N}\right)$.

By early March 1996, the eddy has moved to $37^{\circ} \mathrm{W}$ and the buoy tracks define an inner cool water region (Figure 6A). Buoy 25684 leaves the eddy in a warmer water band. This buoy moves to a warm water region (W) where the track or flow curves anticyclonically. The Subtropical Front appears as a cooler boundary to the north near $35.5^{\circ} \mathrm{N}$ in the west.

By early April, Storm 0 is against the eastern side of the MAR near $37.5^{\circ} \mathrm{W}$ (Figure $6 \mathrm{~B}$ ) without an apparent sea surface signature. A warm anticyclonic region (W) occurs in the north-east (buoy 5032 went clockwise around this region subsequently, see Figure 3 and later Figure 11). The Subtropical Front is evident near $35^{\circ} \mathrm{N}$ and buoy 25684 (now undrogued) moves eastward across the MAR in this cooler region giving a winter minimum sea surface temperature of $16.6^{\circ} \mathrm{C}$ for the cool side of the Subtropical Front. By the end of April/beginning of May, Storm 0 is on the MAR near $38.5^{\circ} \mathrm{W}$ and the next Storm, Storm 1, has 

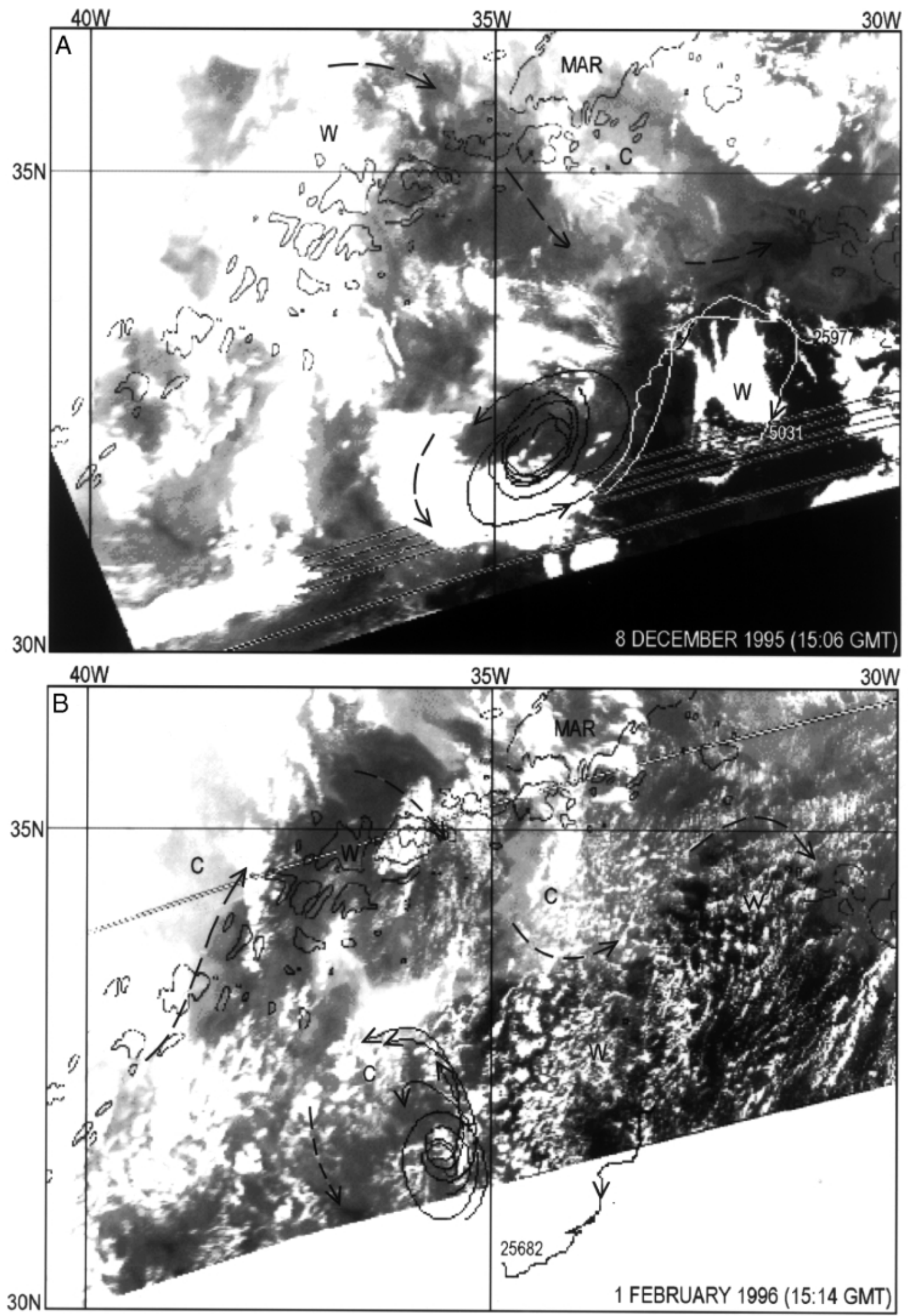

Figure 5. Combined Lagrangian and satellite infrared observations of the subtropical cyclonic eddy (Storm 0). (A) 8 December 1995. (B) 1 February 1996. The duration of the tracks, the identification code and depth of the drogue for the buoys are given in Table 2. Dashed arrows show known rotation sense for Storm 0 and suggested flow based on temperature contrast structures, generally with cool water to the left of the direction of flow. $2000 \mathrm{~m}$ contour identifies the position of the MAR. 


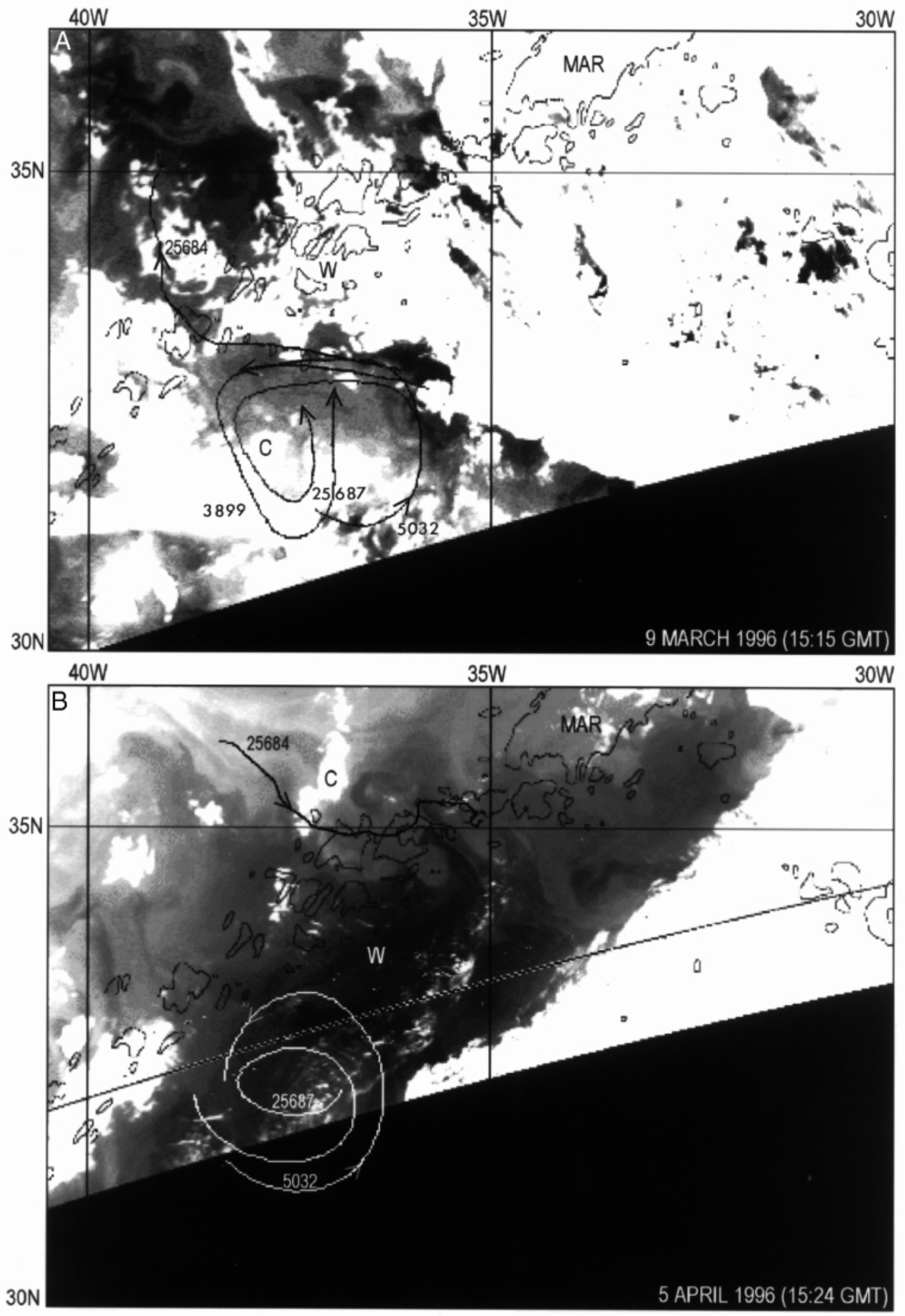

Figure 6. Combined Lagrangian and satellite infrared observations of the subtropical cyclonic eddy (Storm 0). (A) 9 March 1996. (B) 5 April 1996. 
now reached the original CD97 October survey region with centre at $33^{\circ} \mathrm{W}$ (near Mooring 156). Later (6 June 1996), a North Atlantic section near $32.5^{\circ} \mathrm{N}$ by HMS 'Hecla' showed the centre of Storm 1 near $33.7^{\circ} \mathrm{W}$.

Storms, cyclonic eddies or their initial perturbations, are often first clearly apparent near $25^{\circ} \mathrm{W}$ (altimeter data). They generally develop in intensity as they move west near $33^{\circ} \mathrm{N}$. Some reach the MAR, some decay, others appear to elongate and split and may be partially reabsorbed back into the AC. Generally, Storms do not have a clear SST signature but over simplifying and idealizing, four surface temperature signatures may indicate the presence of a Storm. (i) a cool oval region $\sim 100-200 \mathrm{~km}$ scale may be present. An example is shown in Figure 7. Although this eddy might be about eight months old in October 1992 (based on its longitude, $32.6^{\circ} \mathrm{W}$, with initial development stages near $25^{\circ} \mathrm{W}$ ), it appeared to diminish in intensity in January 1993 and merge with other eddies or the AC in February 1993 near the MAR. The structure was about $100 \mathrm{~km}$ to the north of Storm 0 near the same longitude ( in October 1995) and was therefore perhaps less resolved from the AC. Further signatures are (ii) a 'doughnut' structure with warm centre surrounded by cooler region with a $\sim 300 \mathrm{~km}$ external scale (Figure 5A); (iii) a cooler centre surrounded by a streak of warmer water at a $\sim 200 \mathrm{~km}$ scale (Figure 6A); and (iv) as in (i) but 'sock-like' with cool region linked to the Subtropical Front (see later Figure 12). Structures like (i) are believed to reflect the upward displacement of the interior isotherm structure, whereas (iv) results from the movement or advection of surface water. Any of these structures may indicate the presence of the cyclonic eddy. Adjacent warm water regions of similar scale $(\sim 300 \mathrm{~km})$ tend to be anticyclonic, particularly if to the north and partially surrounded by cold water features. Further eddy or meander structures exist on the Subtropical Front and these temperature features are also propagating westward (see Halliwell \& Cornillon, 1989; Cipollini et al., 1997). The temperature structure giving the position of the Subtropical Front is examined in section 3.5. using individual satellite infrared images, but in conjunction with seatruth (Lagrangian tracks and in situ sea surface temperature measurements), which differentiates this work from other infrared remote sensing studies of the region.

\subsection{Seasonal cycles of sea surface temperature in the subtropical region}

Since the Argos buoys are each transmitting $\sim 10$ calibrated surface $(\sim 0.5 \mathrm{~m}$ depth) temperature measurements a day, seasonal temperature cycles are derived from in situ data rather than from remote sensing. Relevant calibrated temperatures for the infrared images presented are given in Figure 8A. The temperature contrast in the region is typically about $2^{\circ} \mathrm{C}$ from $31^{\circ} \mathrm{N}$ to $35^{\circ} \mathrm{N}$ with an ' $18^{\circ} \mathrm{C}$ Water' minimum in the Subtropical region in winter and a maximum summer temperature of $\sim 26^{\circ} \mathrm{C}$. The temperature sensors on the buoys showed that the subtropical water to the south tends to be only $\sim 0.7^{\circ} \mathrm{C}$ warmer than the eddy surface temperature and so the eddy is unlikely to show a marked advective temperature signature. Any initial temperature contrast appears to be quickly lost. Although we do not envisage the formation process to be the same as Gulf Steam Rings, it is well known that cold core rings quickly lose their initial temperature contrast (Dewar, 1986). The surface temperature of the eddy cycles seasonally much the same as the other selected temperature characteristics (Figure 8A) so it would be quite wrong to suggest that the temperature of the eddy can be used to estimate the time of its formation.

The Subtropical Front itself tends to have about a $1{ }^{\circ} \mathrm{C}$ temperature contrast. As a reference temperature for the Subtropical Front, we present an annual cycle derived from temperature sensors on two drogued buoys in the region. One (3916) remained drogued in the Azores Current for $\sim 1$ year; the other (3909) recirculated in the Azores Current and northern Counterflow for 606 days. The mean seasonal cycle (Figure $8 \mathbf{B}$ ) is therefore a climate reference (for global change for example) for near the middle to northern side of the Azores Current or middle to cool side of the Subtropical Front, with the observations $(1992 / 1993)$ centred near $20^{\circ} \mathrm{W}$. The winter minimum, $\sim 17^{\circ} \mathrm{C}$, is cooler $\left(\sim 1^{\circ} \mathrm{C}\right)$ than the Subtropical Water minimum temperature showing that the STF/AC is the northern boundary for $18^{\circ} \mathrm{C}$ Water. The mean temperature is $\sim 20^{\circ} \mathrm{C}$ (cf. Hernández-Guerra \& Nykjaer, 1997) and the temperature range is $6.5^{\circ} \mathrm{C}$.

\subsection{Diffusion in Storms}

Over a period of $\sim 200 \mathrm{~d}$, buoy and float tracks have spread over $1500 \mathrm{~km}$ in an east/west direction due to westward travel in the eddy and southern counterflow and relatively rapid eastward travel in the Azores Current. North/south spreading was about a half or a third. Diffusion in the eddy itself is considerably smaller and an estimate can be made from the rate of loss of buoys and floats (or particles) from the eddy (Table 1).

The loss against time of 15 particles deployed in Storm 0 within a few days of each other is illustrated in Figure 9. From a practical point of view, it shows that for 15 particles deployed between 40 and $770 \mathrm{~m}$ depth only four remained in the eddy after 180 days. From a planning point of view, it would be necessary to deploy at least four buoys (carefully and effectively drogued) or floats to track the position of such an eddy for half a year. The gradient of the loss curve increases with time near $200 \mathrm{~d}$ so it will be difficult to track such an eddy for say 250 days. A further deployment near the eddy centre, as was attempted from HMS 'Hecla', is necessary to extend the tracking period (see Figure 3; Table 1).

For estimates of diffusion, we take the loss curve drawn through the larger dots. The smaller dots labelled 1 to 6 which are the first six particles to leave the eddy are not taken into account for the reasons given in Table 1 . The mean radius, $r$, at which buoys cease to orbit the eddy centre was estimated at $97 \mathrm{~km}$ (not significantly different from $100 \mathrm{~km}$ ). Account was taken for the fact the eddy and orbits were often elliptical by averaging semi-major $(a)$ and semi-minor $(b)$ axes; $b / a$ was typically 0.8 in the outer region of the eddy. Three particles (labelled 1, 3, 5, Table 1) were deployed in the region of maximum azimuthal flow (near $95 \mathrm{~km}$ radius) so these particles were already nearly out of the eddy (though there is some probability that they 


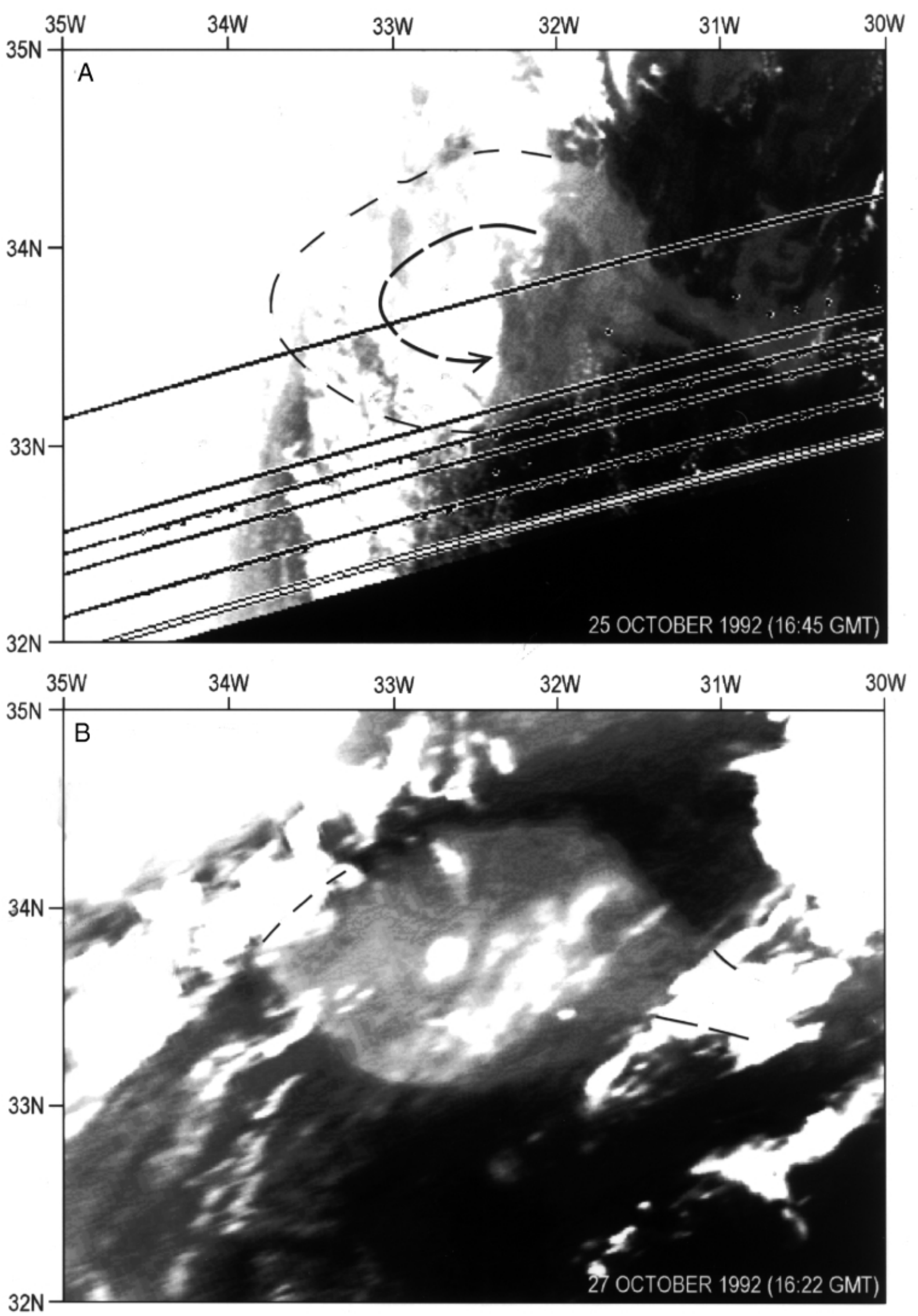

Figure 7. Infrared signature (image contrast enhanced) of a cyclonic eddy (broken arrow indicating rotation) showing cool oval region with major axis of $\sim 200 \mathrm{~km}$ (A) 25.10.92 and (B) 27.10.92. Dashed lines show contrast features from the image not obscured by cloud. 

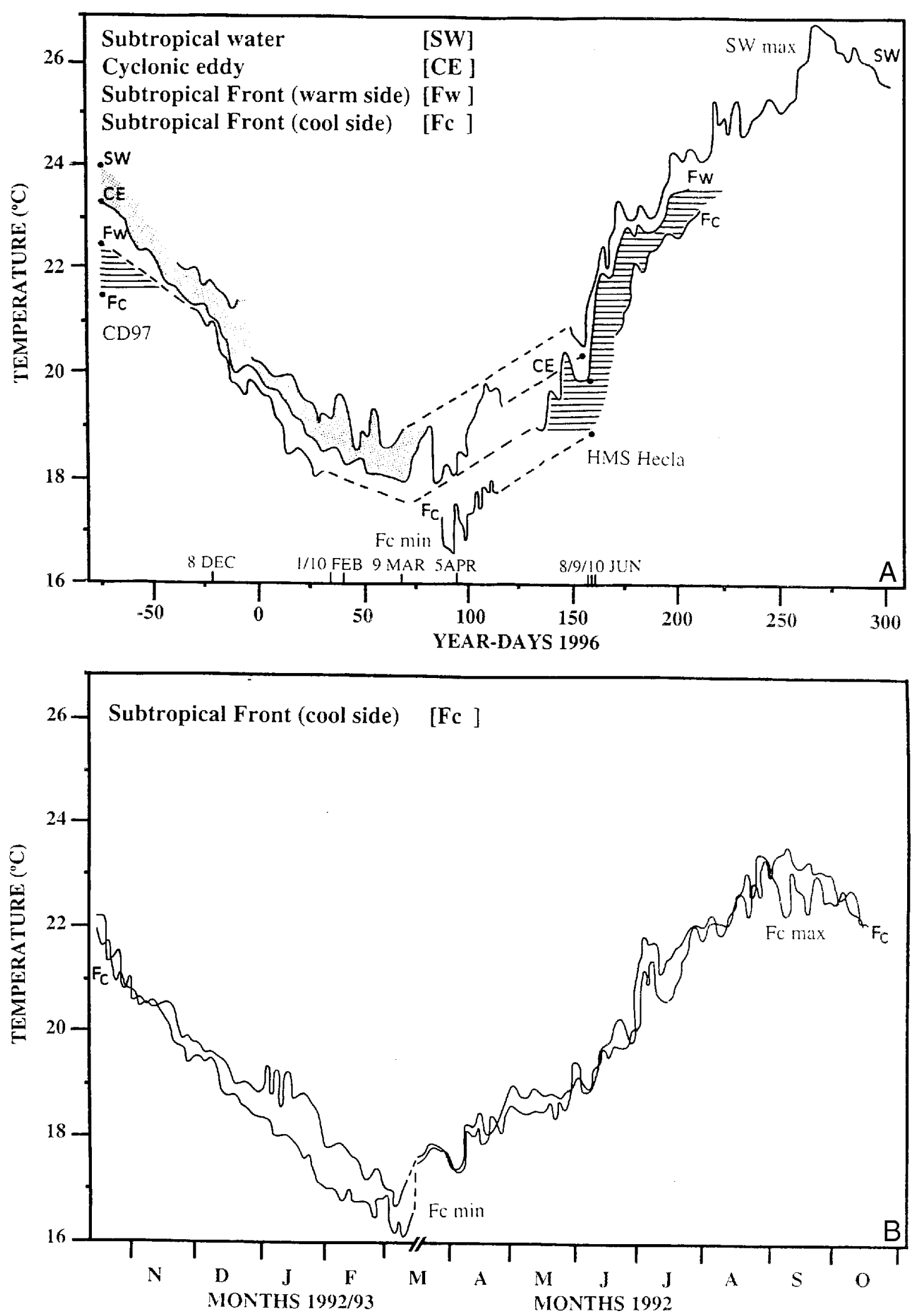

Figure 8. (A) In situ surface temperature from the calibrated temperature sensors on the buoys and from cruise data. The lines represent the cool $(\mathrm{Fc})$ and warm $\left(\mathrm{FW}_{\mathrm{w}}\right)$ side of the Subtropical Front $\left(\sim 34-35^{\circ} \mathrm{N}\right)$, the Subtropical Water to the south (SW; $\left.\sim 30-31^{\circ} \mathrm{N}\right)$ and in the region of the cyclonic eddy $\left(\mathrm{CE} ; \sim 31-33^{\circ} \mathrm{N}\right)$. The values were taken between $25^{-}-40^{\circ} \mathrm{W}$. Discrete values in mid October and early June are taken from CD97 and HMS 'Hecla' sea surface data. The region shaded with dots highlights the potential contrast of the surface cool signature of the cyclonic eddy Storm 0 (CE) with respect to warmer subtropical waters $(\mathrm{SW})$; the region shaded with lines highlights the temperature difference across the Subtropical Front $\left(\mathrm{F}_{\mathrm{w}}-\mathrm{Fc}_{\mathrm{c}}\right)$. Dates of infrared images with Lagrangian tracks are marked and the corresponding temperature values can be used to calibrate the relative thermal contrast of the images. (B) Annual cycle of temperature in the Subtropical Front region (from CD66 drogued buoy deployments; see text for details). 


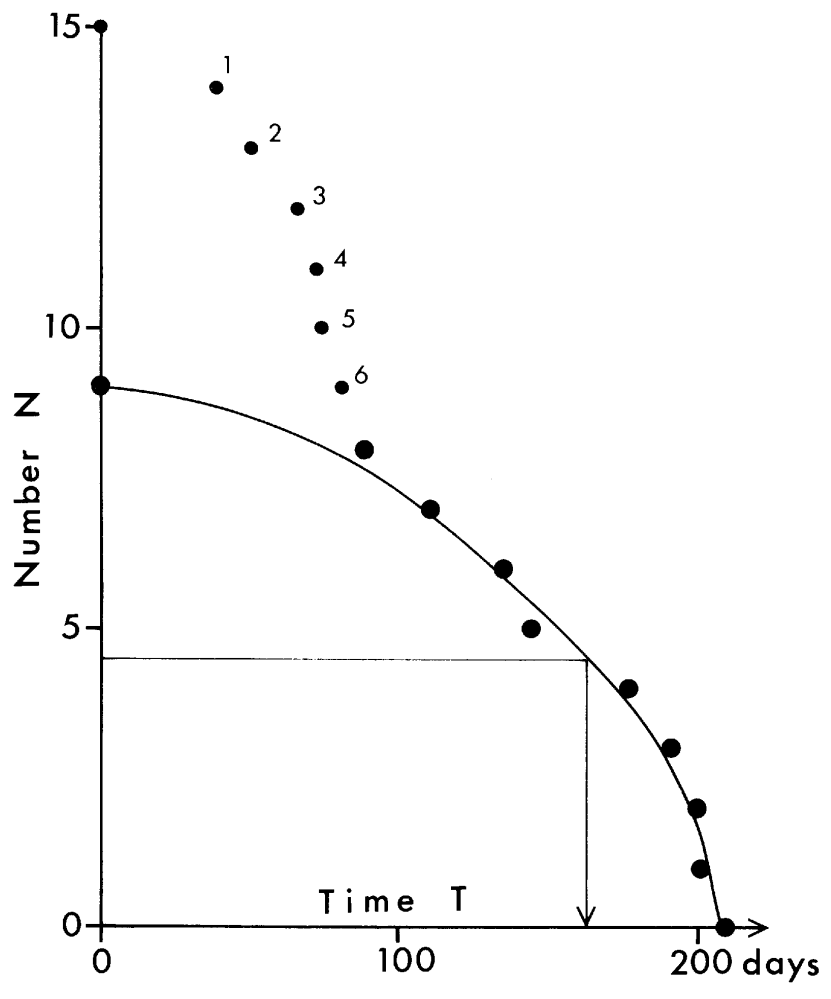

Figure 9. Attrition diagram or loss of particles (buoys and floats) from Storm 0 (see text for details). N is the number of particles orbiting the eddy centre against time $\mathrm{T}$ in days.

may diffuse inwards) and are not included in the diffusion estimate. It is remarkable that particles do not remain in the eddy beyond a radius of $\sim 100 \mathrm{~km}$ where the azimuthal currents are still in excess of the westward eddy speed (see Flierl, 1981). Perhaps diffusion increases markedly to oceanic values in this outer region or perhaps particles are removed by the eastward flow or AC.

Buoys with shallow drogues or buoys suffering drogue loss were not retained or strongly trapped by the eddy so points labelled 2 and 4 are discarded. This is consistent with a mixed layer with little temperature signature with respect to the surrounding water. Trapping will not occur at depth where the azimuthal currents are reduced. ALACE 25973 (point 6, $780 \mathrm{dbar}$ ) is not included in the loss curve of bolder points so that the results are more representative of shallower conditions. The remaining nine particles had initial orbits with a mean radius $r=33 \mathrm{~km}$. Hence for the depth range, $d$, where $100 \mathrm{~m}<d<750 \mathrm{~m}$, with mean depth $\sim 230 \mathrm{~m}$, the mean increase in radius from $33 \mathrm{~km}$ to $100 \mathrm{~km}$ with time is $\sim 430 \mathrm{~m}$ a day. We do not know if the rate depends on radius or even whether there is a radial component to the eddy flow. The drogued buoy in Meddy Pinball looped into the centre of the meddy after 16 orbits in the core (Pingree, 1995). The radial rate derived from the present study, although small compared with oceanic spreading, is considerably larger than the values found for the cores of anticyclonic Bay of Biscay eddies or Swoddies, which showed typical radial speeds of $\sim 100 \mathrm{~m}$ a day (Pingree, 1994). These estimates were made within $\sim 20 \mathrm{~km}$ of the eddy centre. The maximum azimuthal currents in these smaller anticyclonic eddies occur at a radius of about $30 \mathrm{~km}$.

Now assume that the diffusion or radial spreading up to the radius of maximum swirl flow and just beyond with $r \sim 100 \mathrm{~km}$ can be parameterized by an apparent horizontal diffusion coefficient (or a Fickian diffusion coefficient if constant with time) $D$. Then, for a point release, the bounding radius containing half the particles after time, $t$, is given as

$r^{2}=0.69 \times(4 D t)$

Reference to Figure 9 shows that 4.5 particles are within $r=100 \mathrm{~km}$ (or half are still retained by the eddy) at $t=160$ days, giving $D=2.6 \times 10^{2} \mathrm{~m}^{2} \mathrm{~s}^{-1}$, about 100 times larger than derived for Biscay Swoddy cores (Pingree \& Le Cann, 1992). A small correction for the finite size $(r \sim 33 \mathrm{~km})$ of the initial release can be estimated. For constant diffusion, the probable radius, $r_{p}$, or radius with maximum number of particles is given as

$r_{p}=(2 D t)^{1 / 2}$

Hence with $D=2.2 \times 10^{2} \mathrm{~m}^{2} \mathrm{~s}^{-1}$, it will take about 29 days for the maximum concentration of particle to move from the centre to a radius of $33 \mathrm{~km}$ and this value of $D$ is consistent with (1) with $r=100 \mathrm{~km}$ if $t$ is increased to $t=189$ days. The overall diffusion values are little changed $(\sim 10 \%$ increased, and not considered significant) if ALACE 25976 (at 760 dbar) ranked 11 is removed from the loss plot and buoy 5031 (drogue at $40 \mathrm{~m}$ ), ranked 2, is included in the loss plot so that conditions now represent the upper $\sim 500 \mathrm{~m}$ of the water column.

We now imagine that the eddy is uniformly covered with many particles and following Carslaw \& Jaeger (1959) estimate the time, $t_{1 / 2}$, for the central concentration to fall to half its original concentration from

$t_{1 / 2}=0.2 \times r^{2} / D$

The value, $t_{1 / 2} \sim 100$ days, appears rather small in view of the fact that individual eddies can be followed for several hundred days (see later section 3.8.2.). Effective decay rates are likely to be faster as energy can be lost by elongation and splitting. We may have overestimated diffusion since buoys and floats are not true Lagrangian particles, representing conditions at a fixed depth (buoys) or related to a fixed pressure (subsurface floats) rather than at a fixed temperature or density. Alternatively, the estimate is realistic and the apparent long lifetime of some eddies results from merging with other nearby eddies or a wavelike transfer of energy between regularly spaced eddies with a clear wavelength or energy from wavelike meanders or eddies associated with the adjacent eastward Azores Current.

\subsection{Subtropical Front position and structure}

The winter 1996 (composite image of 1 and 9 February, Figure $10 \mathrm{~A})$ extends Figure $5 \mathrm{~B}$ to the east $\left(\sim 20^{\circ} \mathrm{W}\right)$ showing further cold cells $(\mathrm{C})$ or southern meanders of the Subtropical Front near $30^{\circ} \mathrm{W}$ and $24.5^{\circ} \mathrm{W}$. The pattern extends from $25^{\circ} \mathrm{W}$ to $40^{\circ} \mathrm{W}$ and has a wavelength of $450 \mathrm{~km}$. Buoy 25977 (drogued at $200 \mathrm{~m}$ depth; 

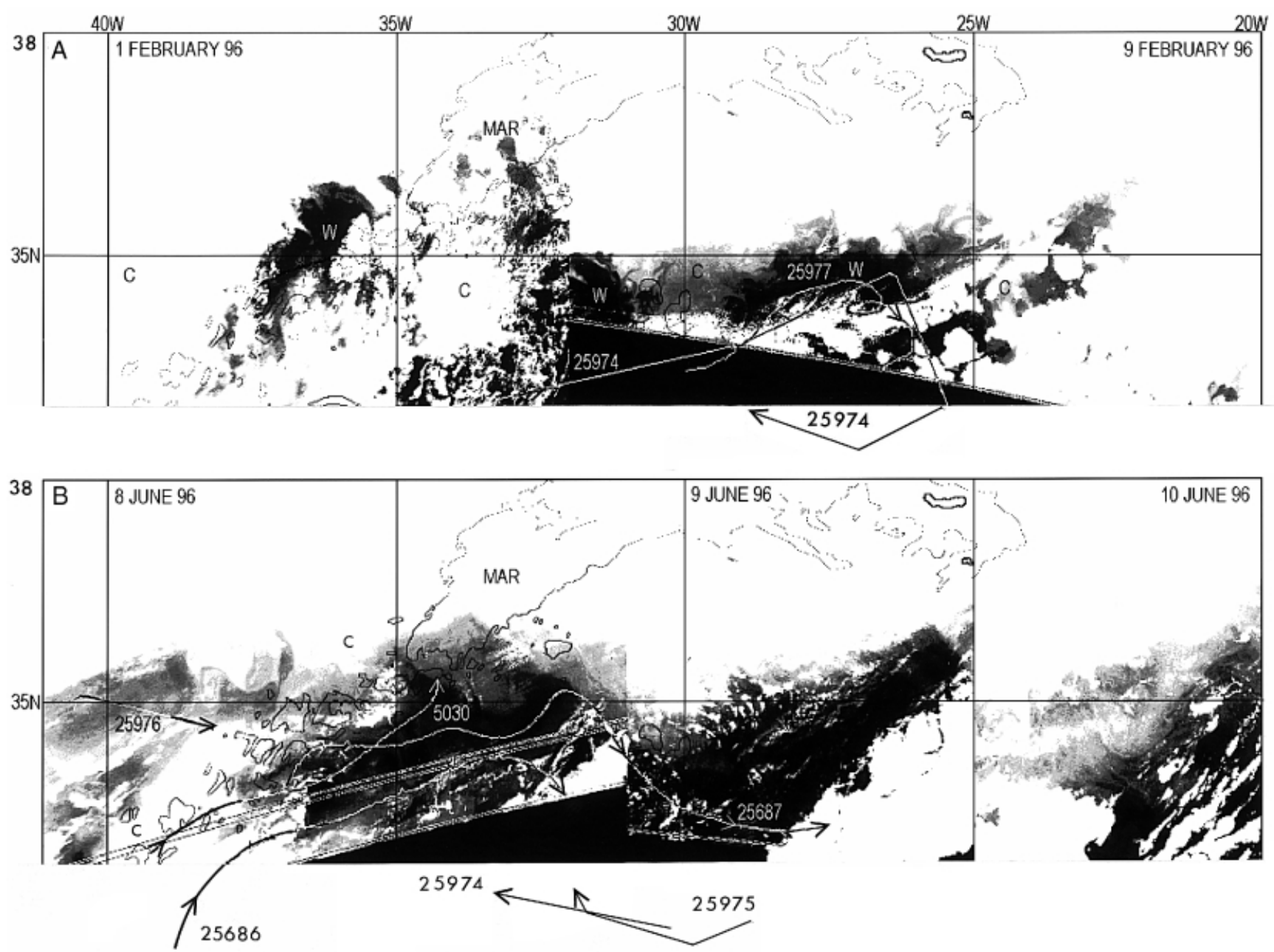

Figure 10. Combined Lagrangian and satellite infrared observations of the Subtropical Front (from $40^{\circ} \mathrm{W}$ to $20^{\circ} \mathrm{W}$ ). (A) Winter 1996 (composite image of 1 and 9 February). W (warm) and C (cold) regions indicated. (B) Early summer 1996 (composite image of 8, 9 and 10 June). The duration of the tracks (of the Argos buoys and ALACE floats), the identification code and depth of the drogue for the buoys are summarized in Table 2. The remote sensing observations in (B) are continued to the east in Figure 2 (4 June 1996) which shows the Subtropical Front reaching $10^{\circ} \mathrm{W}$. The $2000 \mathrm{~m}$ contour shows the Mid-Atlantic Ridge (MAR). Sea level anomaly of cool structure (cyclonic) near $33^{\circ} \mathrm{N} 23^{\circ} \mathrm{W}$ can be seen in Figure 16 .

see Figure 5A) left the eddy at an early stage ( $\sim 40 \mathrm{~d}$ after its release), found the eastward flow near $33.5^{\circ} \mathrm{N} 32.5^{\circ} \mathrm{W}$ and moved about $540 \mathrm{~km}$ to $26^{\circ} \mathrm{W}$ at a mean speed of $\sim 12 \mathrm{~cm} \mathrm{~s}^{-1}$. ALACE 25974 left the eddy $55 \mathrm{~d}$ after its deployment and followed buoy 25977 eastward in the Azores Current at a mean speed of $\sim 20 \mathrm{~cm} \mathrm{~s}^{-1}$ to near $26^{\circ} \mathrm{W}$. Some warm frontal water flowing east adjacent to cool regions subsequently flows south and then back to the west. This is shown by the track of ALACE 25974 (which was near a pressure of 210 dbar where the temperature was $17^{\circ} \mathrm{C}$, in February 1996, when this subsurface float moved south) and buoy 25977 which left the Subtropical Front in a clockwise sense near the same position. The sea surface temperature of buoy 25977 was $17.8^{\circ} \mathrm{C}$ on 9 February in the warm water region where this buoy was turning anticyclonically south. ALACE 25974 found the region of flow reversal about two degrees to the south and moved westwards in late February and March at a mean speed of $\sim 10 \mathrm{~cm} \mathrm{~s}^{-1}$.

The early summer 1996 (composite image of 8, 9 and 10 June, Figure 10B) period was chosen as it corresponded to the North Atlantic crossing of HMS 'Hecla' near $32.5^{\circ} \mathrm{N}$ in the region. The satellite images show the Subtropical Front outcrop near $35^{\circ} \mathrm{N}$. There is a cool extension stretching along the MAR which contains Storm 0 near $39^{\circ}$ W. Storm 0 was first clearly evident in the altimeter structure in January 1995 (near $25^{\circ} \mathrm{W}$ ) and so was about 1.5 years old when on the MAR. The cool region stretching along the MAR to the cool region of the STF represents a further elongation and splitting (as occurred in January, e.g. Figure 5B) of the structure and clearly evident in the altimeter data as a low pressure sea level anomaly. Drogued buoy (25686, 5030 and 25687) tracks identify the Azores Current (or Subtropical Front) clearly with water moving (ENE) along the eastern side of the MAR. From early June to July, the sea surface temperature contrast between buoy 5030 and buoy 25686 defining a $100 \mathrm{~km}$ wide Azores Current stream (with mean temperature near $21.5^{\circ} \mathrm{C}$ ) was $1.3^{\circ} \mathrm{C}$, with cooler surface water to the left of the flow direction. The mean speed of the flow in a direction along the MAR across a $100 \mathrm{~km}$ width of the stream was $25 \mathrm{~cm} \mathrm{~s}^{-1}$ (10 day average). We note that to a depth of only $200 \mathrm{~m}$ this represents a transport of $5 \mathrm{~Sv}$. Argos buoy 25687 (drogued at 
$200 \mathrm{~m}$ depth), that tracked the eddy for the longest period, showed a $\sim 1000 \mathrm{~km}$ route of the $\mathrm{AC}$, as it moved eastward from $37^{\circ} \mathrm{W}$ to $26^{\circ} \mathrm{W}$ (see Figure $10 \mathrm{~B}$ for partial track). The buoy moved first north-east along the eastern flank of the Mid-Atlantic Ridge (MAR) towards Oceanographer Fracture Zone (near $35^{\circ} \mathrm{N}$ ), then along the western side of the chain of seamounts (Atlantis) extending south-east from the MAR and then eastward over Plato Seamount near $33^{\circ} \mathrm{N}$ at a speed of $28 \mathrm{~cm} \mathrm{~s}^{-1}$ (20 day mean). The warm water to the south of buoy 25687 (moving eastward in the Azores Current) is moving back westwards. This is shown by the tracks of ALACE 25974 (mean temperature $\sim 16.9^{\circ} \mathrm{C}$ near 185 dbar) and ALACE 25975 (mean temperature $\sim 13.8^{\circ} \mathrm{C}$ near $426 \mathrm{dbar}$ ) which went westward in June. These deeper ALACE show that the current structure is not confined to the warm surface water but can be deeply penetrating. ALACE 25976 (near 765 dbar, mean temperature now near $10^{\circ} \mathrm{C}$ ) is moving eastward towards the MAR and crosses the MAR near $34^{\circ} \mathrm{N}$ in July. Buoy 25687 also moved south near $26^{\circ} \mathrm{W}$ (on year-day 200, 1996) and recirculated clockwise over the next 100 days.

The eastward track of both buoys (25977 and 25687) was $\sim 1^{\circ}$ south of the region of maximum thermal contrast or surface outcrop of the Subtropical Front (near $35^{\circ} \mathrm{N}$ ) and the drogued buoys are measuring flow at $200 \mathrm{~m}$ depth (drogue depth). The flow above $200 \mathrm{~m}$ rides on the $200 \mathrm{~m}$ near-geostrophic flow, so the upper layer warm water above (evident in the imagery) will also be flowing east near the front as will the warm water to the north of the buoys. Buoys and ALACE show that the same warm water properties can flow back westwards in the south of the region (near $30^{\circ}-32^{\circ} \mathrm{N}$ ). Some subtropical flow is recirculating as both ALACE and buoys may then move north and rejoin the Azores Current where they move eastwards again (i.e. southern Subtropical Recirculation track). After about 300 days, ALACE 25974 recirculated back to the AC with east-west track extending for $\sim 900 \mathrm{~km}$ (from $\sim 25^{\circ} \mathrm{W}$ to $\sim 35^{\circ} \mathrm{W}$, see figure 5 in Pingree (1997)).

In summary, the IR imagery can identify the position of the STF outcrop as a temperature contrast in the region. The imagery shows that the drogued buoys and floats are mostly in the warm water adjacent to the cool STF outcrop and the superposed Lagrangian tracks show that this water is moving eastward (AC) although cells of warm water are turning anticyclonically. To the south some warm water is returned westward, some of which later recirculates back eastward in the warm AC. The STF position and structure can be seen in SeaWiFS images (see 3.9). The seasonally varying chlorophyll a SeaWiFS front matches the STF outcrop/IR structure in February and March. Signatures of Storms to the south are most evident in April (image composite for April 1998).

\subsection{Ocean diffusion in the STF region}

The ocean structure and westward moving eddies are spreading particles (drogued buoys and ALACE). Particles that were originally contained in the eddy are shown T $\sim 200$ days after release (Figure 11). The eddy has moved from $33.6^{\circ} \mathrm{W}$ to near $39^{\circ} \mathrm{W}$ and the particles are spread across $\sim 1500 \mathrm{~km}$. An apparent horizontal diffusion $D\left(D_{\mathrm{x}}=\sigma_{\mathrm{x}}{ }^{2} / 2 \mathrm{~T}, D_{\mathrm{y}}=\sigma_{\mathrm{y}}{ }^{2} / 2 \mathrm{~T}\right)$ based on the mean squared x-east $\left(\sigma_{\mathrm{x}}{ }^{2}\right)$ and y-north $\left(\sigma_{\mathrm{y}}{ }^{2}\right)$ separation or displacement from an initial release position (Okubo, 1971) is $D_{\mathrm{x}}=5.1 \times 10^{3} \mathrm{~m}^{2} \mathrm{~s}^{-1}$ and $D_{\mathrm{y}}=1.1 \times 10^{3} \mathrm{~m}^{2} \mathrm{~s}^{-1}$.

After 200 days, all the particles have left Storm 0 and their subsequent positions are used to derive a rms displacement rate in the STF region. A displacement time interval of 40 days was chosen as it was the least common denominator (LCD) for the ALACE position sampling and sufficiently long not to be dominated by the displacements due to coherent eddy orbital motions. The oceanic diffusion values based on mean squared displacements (with respect to the centre of mass or corrected for overall displacements of the water in the sampling region) were $D_{\mathrm{x}}=1.3 \times 10^{4} \mathrm{~m}^{2} \mathrm{~s}^{-1}$ and $D_{\mathrm{y}}=3.9 \times 10^{3} \mathrm{~m}^{2} \mathrm{~s}^{-1}$ for the 40 day period. These estimates are even larger than before and again show preferential spreading in the east/west direction. The eddy, moving particles to the west and losing particles to the AC, does not spread them as fast as oceanic mixing in the region sampled. The apparent diffusion values for the same particles over the next 40 days were $D_{\mathrm{x}}=1.0 \times 10^{4} \mathrm{~m}^{2} \mathrm{~s}^{-1}$ and $D_{\mathrm{y}}=2.0 \times 10^{3} \mathrm{~m}^{2} \mathrm{~s}^{-1}$. Removing the two deeper ALACE tracks from the diffusion estimates so that conditions near $200 \mathrm{~m}$ depth are represented (mean depth $235 \mathrm{~m}$ ) gives similar diffusion values of $D_{\mathrm{x}}=1.3 \times 10^{4} \mathrm{~m}^{2} \mathrm{~s}^{-1}$ and $D_{\mathrm{y}}=2.6 \times 10^{3} \mathrm{~m}^{2} \mathrm{~s}^{-1}$ (mean of both 40 day periods). The anisotropic diffusion is partially attributed to the tendency of particles to move eastwards in the $\mathrm{AC}$ and then return westward in the counterflow region to the south (see Figure 11). Over the 80 day period considered, the mean displacement (with means based on $\sim 2$ year averages or $8 \times 80$ day sampling) of the Subtropical Front region sampled was $1.2 \mathrm{~km} \mathrm{~d}^{-1}$ east and $0.6 \mathrm{~km} \mathrm{~d}^{-1}$ south. The oceanic diffusive values are one to two orders of magnitude greater than the eddy values. A diffusion velocity based on a rms separation gave $7 \mathrm{~km} \mathrm{~d}^{-1}$ for the east/west direction and $2 \mathrm{~km} \mathrm{~d}^{-1}$ for the north/south direction, over the 80 day period considered. The value of $7 \mathrm{~km} \mathrm{~d}^{-1}$ for the ocean can be compared with $0.43 \mathrm{~km} \mathrm{~d}^{-1}$ derived for the radial speed in the eddy. Although diffusion or radial spreading in Storm O was large in comparison to other types of eddies found in the Eastern Basin, it was small in comparison to the apparent oceanic diffusion resulting from the overall effects operating in the STF region.

\subsection{Selected composite image showing Subtropical Front, cold cyclonic and warm anticyclonic structures}

The satellite infrared image for February 1997 (composite image of satellite passes on 4, 5 and 10 February; Figure 12) has been selected from an appraisal of all the available images between September 1995 to March 1997 as it most clearly characterizes the significant sea surface Subtropical Front thermal structure from $10^{\circ} \mathrm{W}-34^{\circ} \mathrm{W}$ $(\sim 2200 \mathrm{~km})$, near $34^{\circ} \mathrm{N}$. Cooler water is present north of $35^{\circ} \mathrm{N}$ and warmer water south of $35^{\circ} \mathrm{N}$ but the structure is convoluted with some order present. Cold water (or water columns with low dynamic height) displaced to the south (where the water columns have larger dynamic height) will develop cyclonic movement and these features represent or will develop into the regularly spaced cyclonic eddies or Storms. This dynamic effect will be augmented by the north-south displacement of planetary 


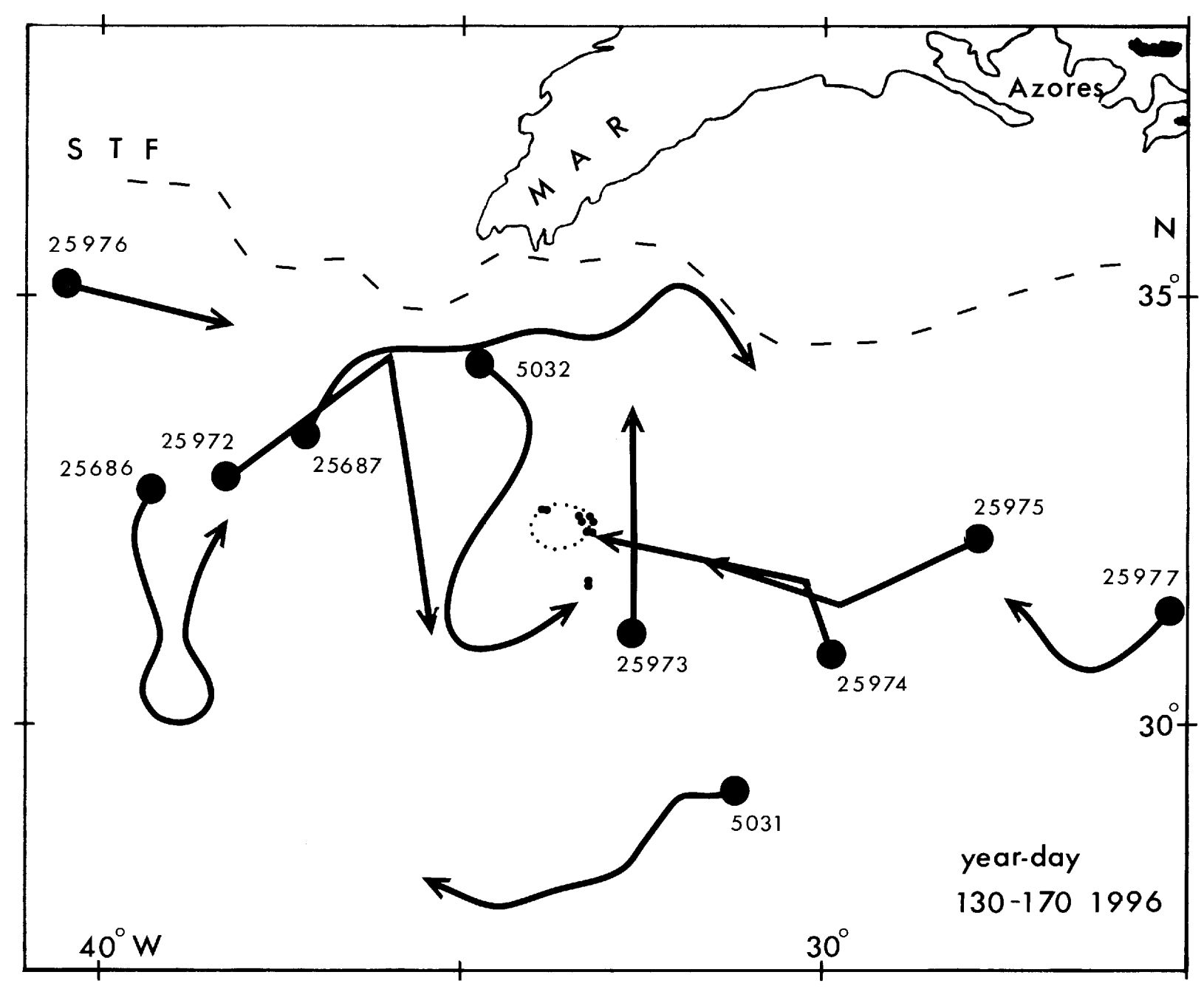

Figure 11. Buoy and ALACE tracks over a 40 day period (year-day 130 (large dot) - 170 (arrow head), 1996) on the warm side of the STF outcrop (position of surface temperature contrast shown dashed is taken from Figure 10B; temperature can be appraised from Figure 8). Small dots are the release positions and the dotted region shows the initial eddy orbits in Storm 0 (the previous year, October/November 1995), except for drogued buoy 25977 and ALACE 25974 which were deployed in the region of maximum azimuthal flow at a distance of $80 \mathrm{~km}$ from the eddy centre. Buoy 5032 is moving anticlockwise around the next Storm, Storm 1, passing westward through the region.

vorticity. The two features marked $\mathrm{C}$ near $32.5^{\circ} \mathrm{N}$ are surface cold water structures. These surface temperature structures will not in general reflect the movement of a water column but will rather show how surface water is drawn into patterns by the presence of the eddies. The two cold water structures can be seen clearly in altimeter data where they are confirmed as low pressure (cyclonic) anomalies (see Figure 13, with data extracted from CLS ftpsite (spike.cst.cnes.fr) for the nearest date corresponding to the western infrared image (4.2.97) that forms the composite of Figure 12). It has not been possible to quantify a relationship between temperature structure and sea level anomaly since the temperature reflects both structure and gradients (i.e. cooler water towards the north) whereas average gradients are largely removed (or hardly present if there are no mean surface currents) in determining the altimeter sea level anomaly from a reference state. We have called these two cold water low pressure Storm signatures, 'Storm 3' and 'Storm 4' (i.e. $\mathrm{S}_{3}$ near $30.5^{\circ} \mathrm{W}$ and $\mathrm{S}_{4}$ near $25.5^{\circ} \mathrm{W}$ with a separation of $\sim 460 \mathrm{~km}$ ). We note that the cool patch 'C' representing $\mathrm{S}_{3}$ does not correspond quite with the centre of the altimeter structure and that cold and warm (to the south) surface water regions will be turned cyclonically by the eddy flow itself. Storm 2 is $\sim 500 \mathrm{~km}$ ahead (west) of $\mathrm{S}_{3}$ and can be seen in the altimeter data, elongated near the MAR (Figure 13). Storm 2 was also measured directly as it passed through the position of Mooring $156\left(32.52^{\circ} \mathrm{N}\right.$ $34.40^{\circ} \mathrm{W}$ ) in December 1996 , resulting in a $2^{\circ} \mathrm{C}$ drop in temperature near $800 \mathrm{~m}$ depth at this position, equivalent to a $\sim 200 \mathrm{~m}$ uplift of isotherms $(P S)$. Buoy 5032 (drogued at $360 \mathrm{~m}$ depth) failed on 3 February 1997 after 470 days, but moved anticyclonically (with a centre near $33.5^{\circ} \mathrm{N}$ $\left.32.5^{\circ} \mathrm{W}\right)$ in the warm water region just $(\sim 130 \mathrm{~km})$ to the north-west of the centre of $\mathrm{S}_{3}$ near the end of January 1997. W (which extends to the west and south) is a warm water feature (with a water column of relatively larger dynamic height) which is displaced north or partially surrounded by cooler water and so the flow here is anticyclonic. The water movement will be eastward along the temperature front near $35^{\circ} \mathrm{N}$ (Azores Current) and then clockwise around the central structure or region of higher 


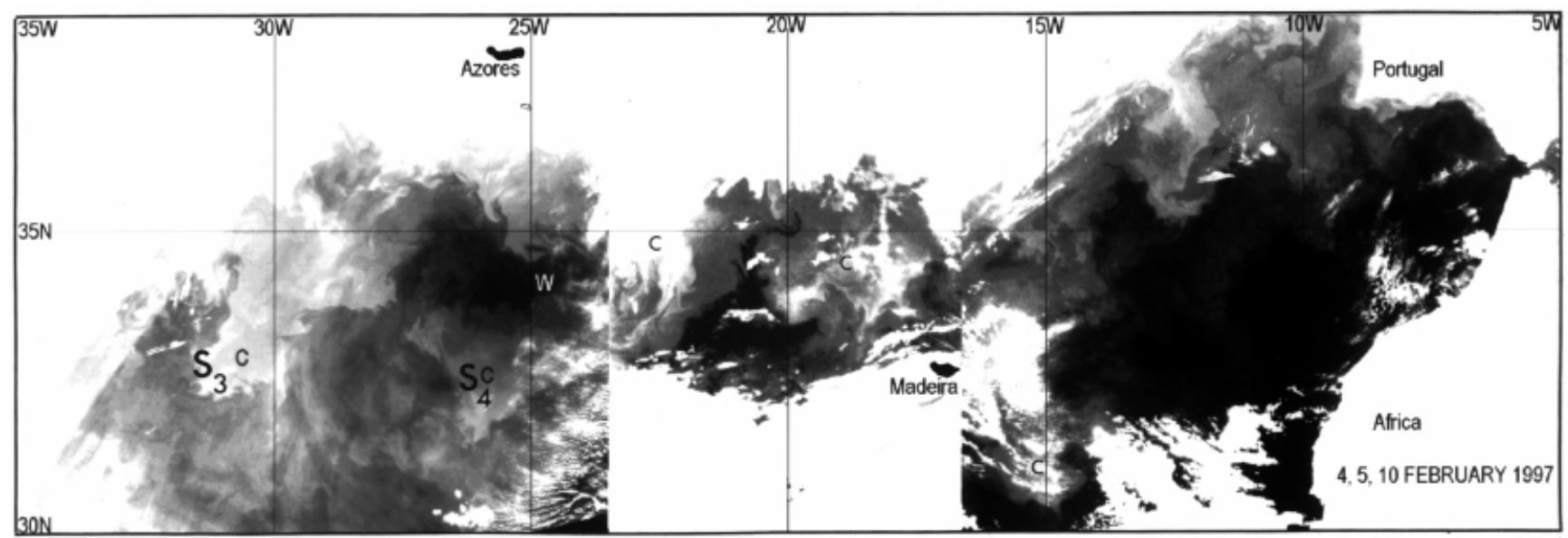

Figure 12. Satellite infrared image for February 1997 (composite image of satellite passes on 4, 5 and 10 February, from west to east). W (warm, anticyclonic) and $\mathrm{C}$ (cold, cyclonic) features indicated in relation to the STF outcrop near $34-35^{\circ} \mathrm{N}$. Cold features near $31^{\circ} \mathrm{W}$ and $26 \mathrm{~W}$ are infrared signatures of Storms $\mathrm{S}_{3}$ and $\mathrm{S}_{4}$ (labelled). Warm and cold features near $25^{\circ} \mathrm{W}$ are shown $\sim 2.5$ months earlier near $23^{\circ} \mathrm{W}$ in Figure 14. Azores (São Miguel), Madeira and coasts of Portugal and Africa labelled.

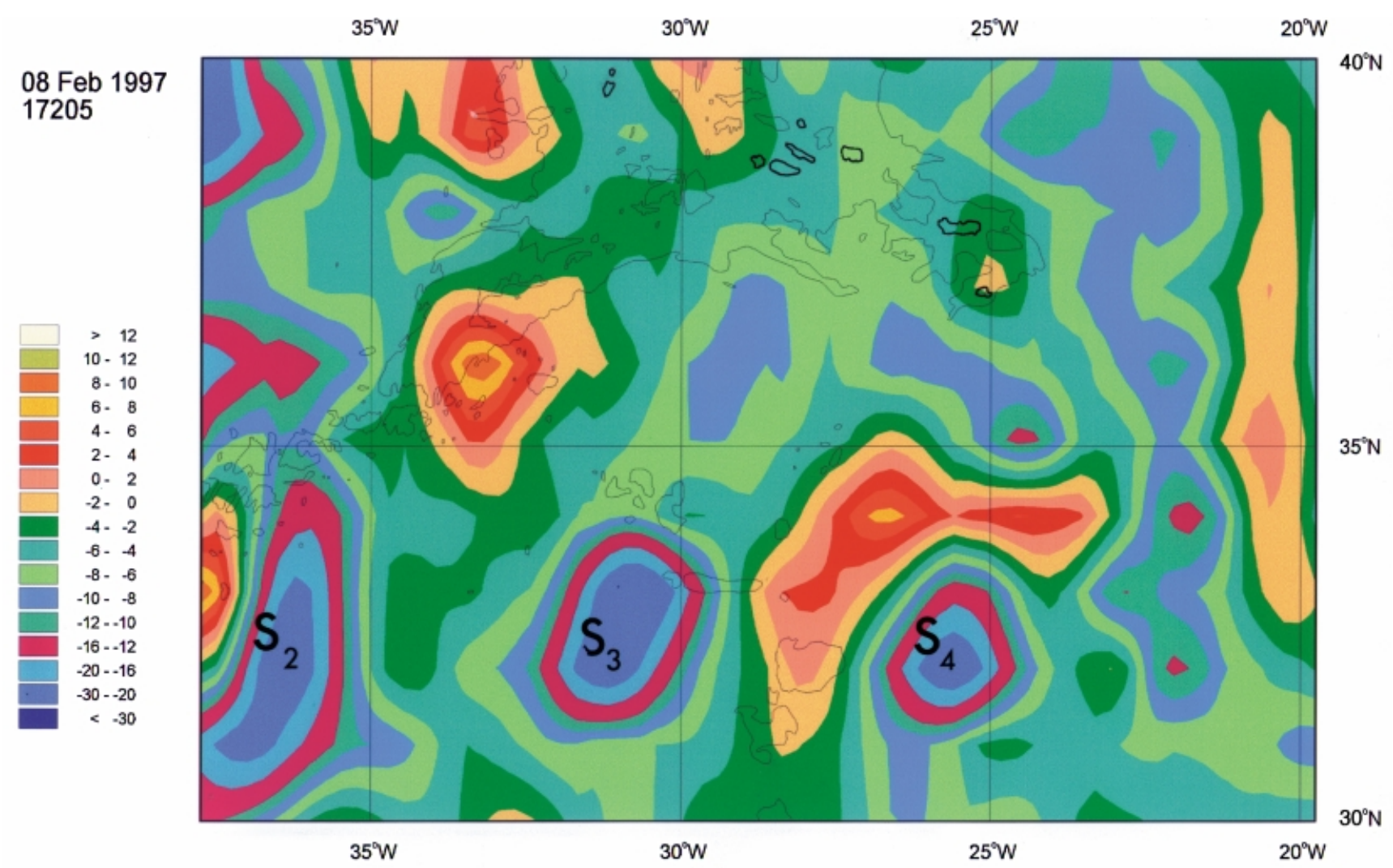

Figure 13. Altimeter sea level anomalies (cm scale in colour) corresponding to Figure $12 . \mathrm{S}_{3}$ and $\mathrm{S}_{4}$ (labelled) are evident near $31^{\circ} \mathrm{W}$ and $26^{\circ} \mathrm{W}\left(\sim 32.5^{\circ} \mathrm{N}\right)$. Orange region to the north of $\mathrm{S}_{4}$ matches the warm water region $\mathrm{W}$ in Figure 12 and blue meridional patch near $23^{\circ} \mathrm{W}$ corresponds to the cold streaks marked c.

sea surface elevation pressure. Just to the east of $\mathrm{W}$ $\left(\sim 23^{\circ} \mathrm{W} 35^{\circ} \mathrm{N}\right)$, the cold streaks also show a clockwise sheared pattern with implied cool flow from the north. Altimeter data confirm a region of high sea surface pressure (Figure 13) associated with the warm water structure (W) and ALACE 25974 turned clockwise around this warm region between December 1996 and March 1997, with mean temperature near $17.8^{\circ} \mathrm{G}$ (i.e. Subtropical Water with larger dynamic height) at 150 dbar. We note that ALACE 25974 has moved from a mean pressure of
220 dbar in Storm 0 (where the mean temperature was $\sim 15.7^{\circ} \mathrm{C}$ ) to $150 \mathrm{dbar}$ in the warmer region of the STF over a period of 450 days. ALACE move upwards in warmer water due to expansion $\left(\sim 50 \mathrm{dbar}^{\circ} \mathrm{C}^{-1}\right.$ at constant salinity) and with age

\subsection{Westward movement of structure}

3.8.1. Storm generation region. Although altimeter data is not affected by clouds and altimeter sea level anomalies show 


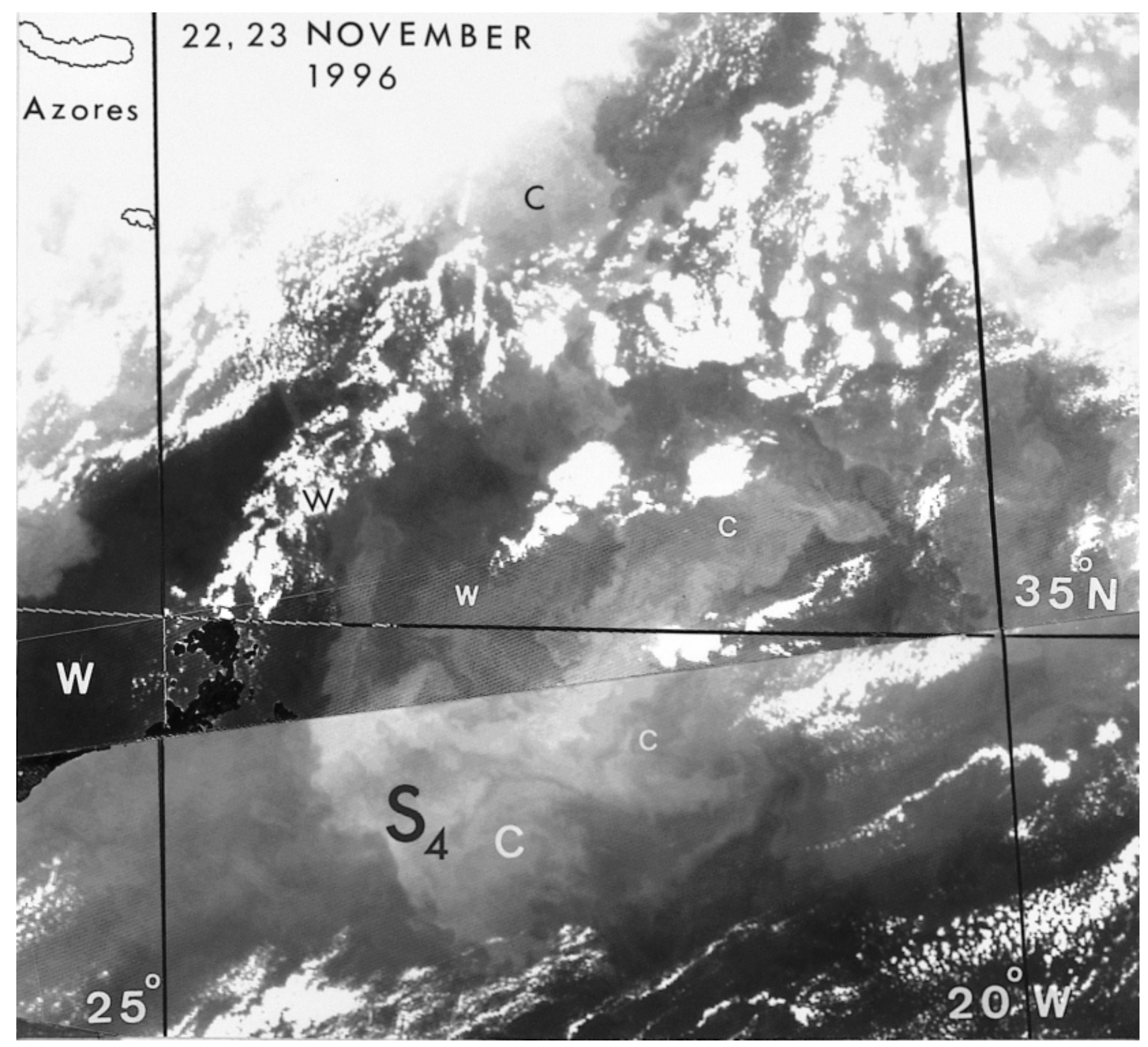

Figure 14. Satellite infrared image for November 1996 (composite image of satellite passes on 22 and 23 November) showing the early stages of $\mathrm{S}_{4}$ (labelled). Cool jet across $35^{\circ} \mathrm{N}$ near $22^{\circ} \mathrm{W}$ (with a connecting irregular filament-like structure to the north) with W (warm, anticyclonic) and C (cold, cyclonic) structure forms a curved front near $24^{\circ} \mathrm{W}$. Azores (São Miguel) shown. The structure is south of the STF outcrop near $36-37^{\circ} \mathrm{N}$.

the eddy structures far more clearly, infrared images can give more detail of structure in the east of the region and may reveal some aspects of the Storm formation process. Infrared image sequences for the east of the region show westward moving thermal structure. The infrared image of 9.1.97 shows $\mathrm{S}_{4}$ near $24.5^{\circ} \mathrm{W}$ (not shown) and the image of 13.3 .97 (also not shown) indicates a position for $\mathrm{S}_{4}$ near $26^{\circ} \mathrm{W}$ giving a westward movement of $\sim 2.5 \mathrm{~km} \mathrm{day}^{-1}$. The warm water anticyclonic cell also moves westward (cf. Figures 12 \& 14). The initial structures generally move westwards more slowly and so the separation scale is typically $460 \mathrm{~km}$ in the east. This infrared image sequence shows that $\mathrm{S}_{4}$ is first evident as part of an anticyclonic/cyclonic dipole type of structure with cool stem extending from the north and directed across $35^{\circ} \mathrm{N}$ near $22^{\circ} \mathrm{W}$ in late November 1996 (Figure
14). The cool stem stretches to $38^{\circ} \mathrm{N}$ and is associated with a cyclonic low pressure sea level anomaly (altimeter data). This shows that Storms can start evolving as far east as $22.5^{\circ} \mathrm{W}$. Eddy energy, or rather meridional motion, of this period is evident in long current meter records in the region near $22^{\circ} \mathrm{W}$ (Müller \& Siedler, 1992) and westward moving cyclonic structures are already present near $18^{\circ} \mathrm{W}$ $\left(33-34^{\circ} \mathrm{N}\right.$ ) (figure 4 of Pingree (1997)). Some early initial infrared signatures may even be observed east of Madeira $\sim 12-13^{\circ} \mathrm{W}$. For example, the AVHRR infrared image of 23 March 1992 (figure 11 of Pingree (1997)) shows warm (anticyclonic) cells separated by cool water extensions, filaments or plumes from the north, with a separation scale of $\sim 370 \mathrm{~km}$, which start near $10^{\circ} \mathrm{W}$, but it is not known whether these most easterly regular features develop into Storms. 


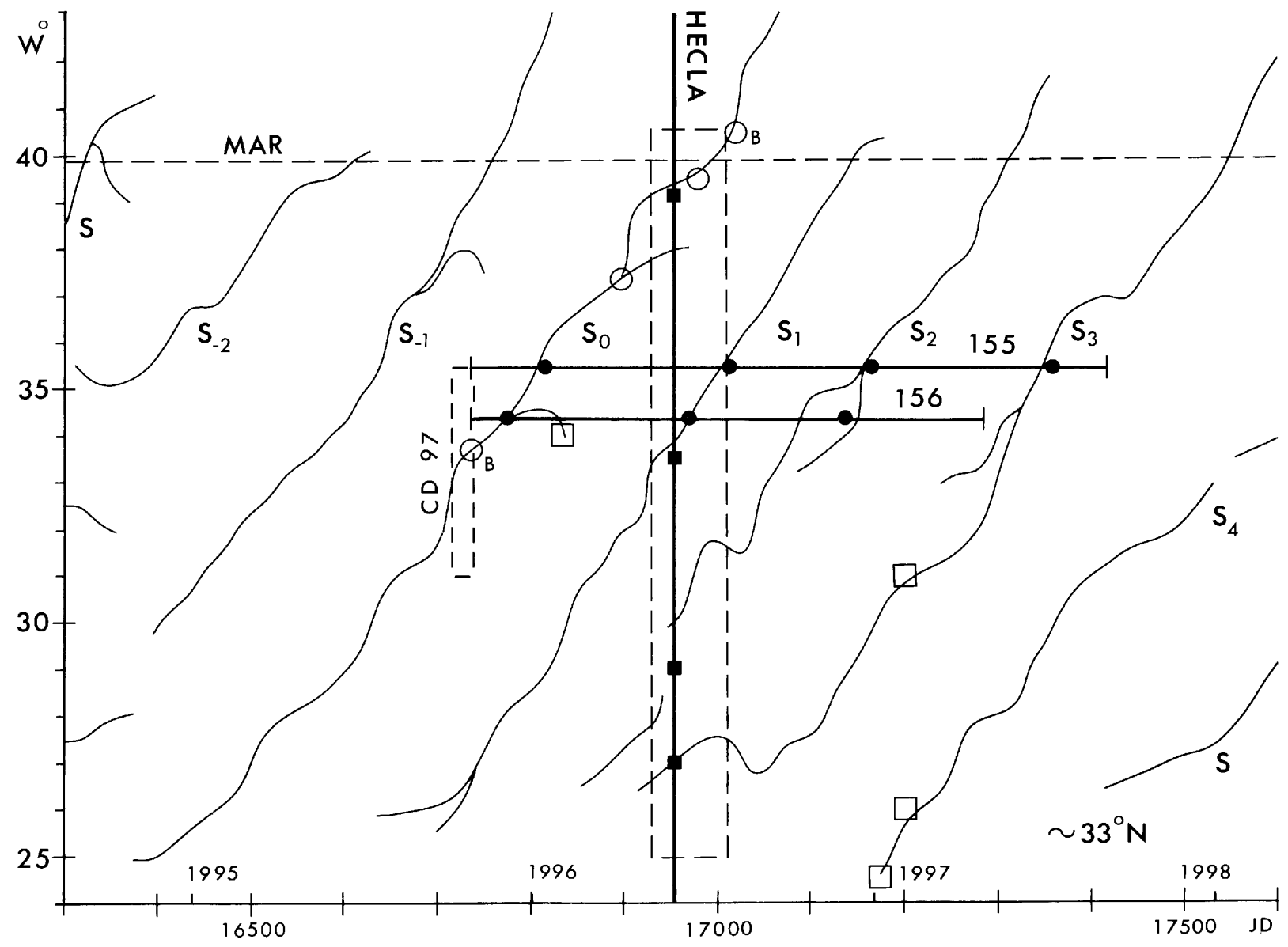

Figure 15. Storm travel curves summarizing conditions near $33^{\circ} \mathrm{N}$, from $24^{\circ} \mathrm{W}$ to $43^{\circ} \mathrm{W}$ over a 3.6 year period (JD 16,300-17,600). Storms $\mathrm{S}_{0}, \mathrm{~S}_{1}, \mathrm{~S}_{2}, \mathrm{~S}_{3}$ were identified by cooling at mooring 155 deployed at $35.5^{\circ} \mathrm{W}$ for two years and Mooring 156 at $34.4^{\circ} \mathrm{W}$ shown as dots. On an Atlantic crossing, HMS 'Hecla' identified upward doming of isotherms or cooling representing $\mathrm{S}_{-1}, \mathrm{~S}_{0}, \mathrm{~S}_{1}, \mathrm{~S}_{2}$ (solid squares) near JD 16,957. Drogued buoy tracks (see Figure 3) are used to estimate the eddy centre of $\mathrm{S}_{0}$ (open circles labelled $\mathrm{B}$ ) and track this eddy across the MAR shown near $39.9^{\circ} \mathrm{W}$ for $32.5^{\circ} \mathrm{N}$. Tracks of eddy centres were then extended from the central region using altimeter data (thin) lines. The track lines are not always continuous and merging and splitting of eddy structure is shown by bifurcation. The open squares correspond to IR signatures (see for example Figure 12 showing $\mathrm{S}_{3}$ and $\mathrm{S}_{4}$ ). The larger dashed window covers the $80 \mathrm{~d}$ period for horizontal diffusion estimates in the STF region. The smaller dashed window represents the RRS ‘Charles Darwin' Cruise CD97 (Plymouth Marine Laboratory, 1995) survey of Storm 0 in October 1995 and the deployment of drogued buoys (see Figure 3) and Moorings 155 and 156.

Storm formation appears to result from excessive southward movement of more northern (from say $\sim 35^{\circ}$ or even $37^{\circ} \mathrm{N}$ ) colder water resulting in an irregular filamentlike structure $(P S)$ which subsequently turns westward and confines warmer (anticyclonic) water to the north (see Figure 12). Scrutiny of the altimeter structures suggests that some smaller low pressure features may originate in the south (near the latitude of Madeira $\sim 32.8^{\circ} \mathrm{N}$ ). Coalescence of structures may occur. Storms may intensify further as they move west into a region of increasing dynamic height (i.e. Subtropical Water). The mean dynamic height increases from 1.66 to 1.78 dyn $\mathrm{m}$ from $20^{\circ} \mathrm{W}$ to $40^{\circ} \mathrm{W}$ along $33^{\circ} \mathrm{N}$, with the most rapid increase occurring near $30^{\circ} \mathrm{W}$ (WOA94, reference level 2000 dbar and average of four seasons).

3.8.2. Summary of Storm positions 1994-1998 near $33^{\circ} \mathcal{N}$. Travel curves summarizing positions of Storms near $33^{\circ} \mathrm{N}$ from 1994 to 1998 are shown in Figure 15. Positions for Storms $\mathrm{S}_{0}, \mathrm{~S}_{1}$ and $\mathrm{S}_{2}$ were given in $P S$ and further Storms,
$\mathrm{S}_{3}, \mathrm{~S}_{4}$, are identified here in IR imagery (Figure 12). $\mathrm{S}_{3}$ was also measured 150 days later as it passed Mooring 155 (Pingree, 2000). Buoy tracks extending over 300 days showed some continuity of Storm 0 from $33^{\circ} \mathrm{W}$ to $41^{\circ} \mathrm{W}$, just across the MAR. Further continuity of structure was derived using altimeter sea level anomalies (from CLS ftpsite) in the region.

A number of general remarks can be made with respect to the travel curves. Eddies travel westward from the Eastern Boundary in the Eastern Basin with further generation of structures in the Western Basin moving westward from the MAR. Although individual patterns (low pressure structures) can be followed for enormous distances, for example $\mathrm{S}_{0}$ from $25^{\circ} \mathrm{W}$ to $50^{\circ} \mathrm{W}$ over a period of $\sim 900$ days, merging and splitting or exchange of eddy structures occurs, so we cannot say that an individual eddy has followed the complete travel curves. In this sense, the structures have wavelike properties. $\mathrm{S}_{-1}$ (Figure 15) appeared to reach Bermuda (to the north) with inputs of energy from other structures which had 


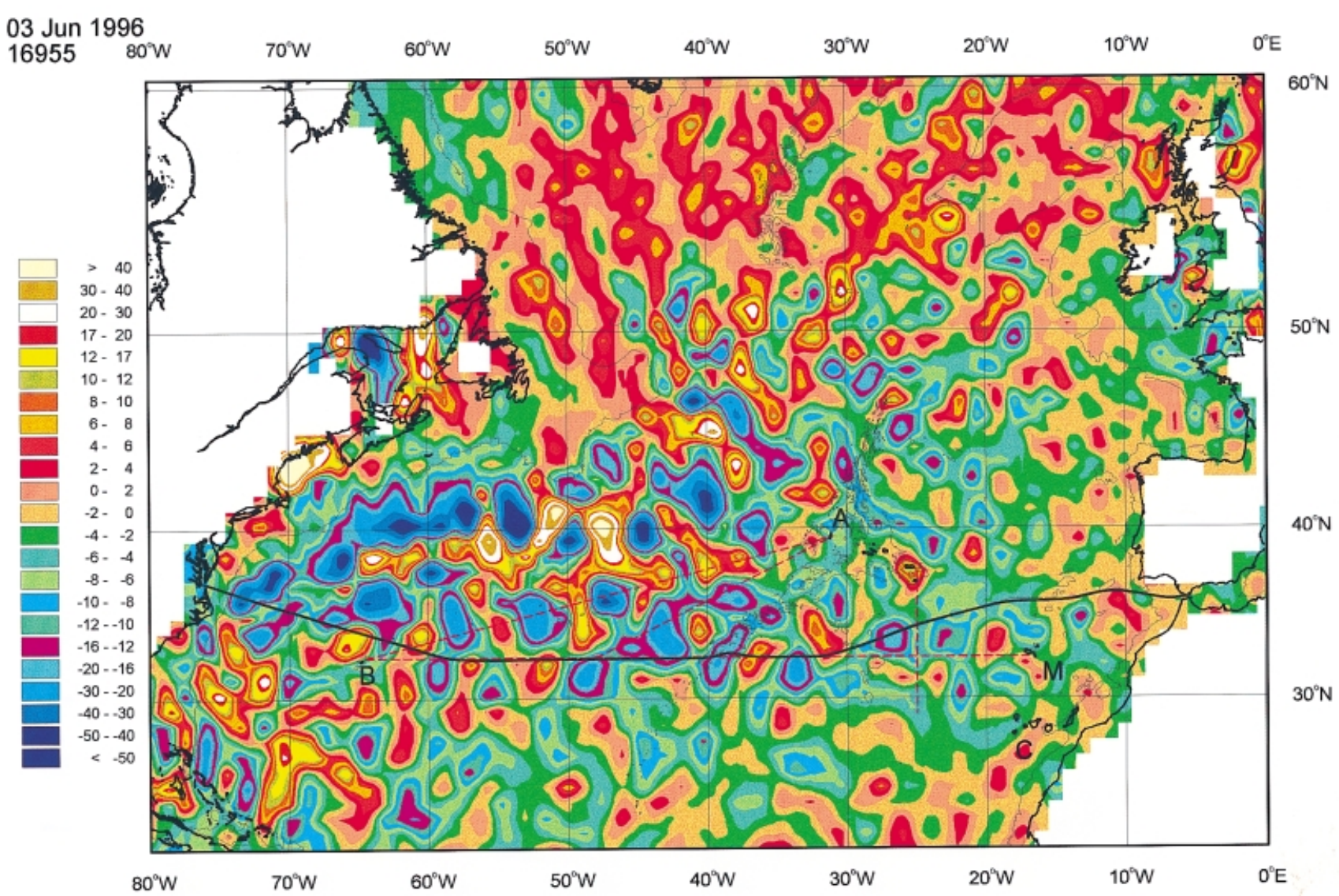

Figure 16. Altimeter sea level anomalies (cm scale in colour) for the North Atlantic (3 June 1996) corresponding to the North Atlantic crossing of HMS 'Hecla' from Norfolk, Virginia (28 May 1996) to Gibraltar (10 June 1996) with track superposed. On 3 June 1996, HMS 'Hecla' was on the MAR near $40^{\circ} \mathrm{W}$. Buoy 1811 was deployed on 4 June 1996 (year-day 156, see Figure 3). A, Azores; B, Bermuda; C, Canary Islands; M, Madeira. Elongated purple/blue feature cut by ship's track across the MAR (near $40^{\circ} \mathrm{W}$ ) contains Storm 0 and cool IR signature is evident in Figure 10B. A more circular purple/blue feature cut near $33.5^{\circ} \mathrm{W}$ is Storm 1 .

their origin in the Western Basin. $\mathrm{S}_{-1}$ was intersected on its north flank by HMS 'Hecla' near $49^{\circ} \mathrm{W}$ in the Western Basin (Figure 16) and could be tracked back to $29^{\circ} \mathrm{W}$ in the Eastern Basin. HMS 'Hecla' cut the southern flank of a further cyclonic structure in the Western Basin that was evident in the altimeter data near $43^{\circ} \mathrm{W}$ that did not have a travel curve in the Eastern Basin. Storm 0 is on the MAR (elongated NE/SW near $39^{\circ} \mathrm{W}$ ), $\mathrm{S}_{1}$ is near $34^{\circ} \mathrm{W}$ and $\mathrm{S}_{3}$ near $27^{\circ} \mathrm{W}$. The structures are clearly not always aligned on $32.5^{\circ} \mathrm{N}$. Figure 16 also shows the marked increased eddy energy in the Western Basin compared to the Eastern Basin which has relatively stagnant regions north and south of $30-35^{\circ} \mathrm{N}$ in the east of the region. The Gulf Steam signature is clearly evident in the west and the Stream or structure splits into two branches near $38^{\circ} \mathrm{N}, 50^{\circ} \mathrm{W}$, in the Western Basin. One branch is the Gulf Stream and structure continuing to the north and then to the north-east, the other branch to the south-east becomes the Azores Current in the Eastern Basin. Similar altimeter sea level anomaly maps show that there is a tendency for Storms to elongate (Figure 13) in the direction of the MAR axis $(\sim \mathrm{NE} / \mathrm{SW})$ and split before crossing the MAR (see $\mathrm{S}_{-1}$ and $\mathrm{S}_{0}$ near $38^{\circ} \mathrm{W}$, Figure 15) and some decay before crossing the Ridge. $\mathrm{S}_{1}$ and $\mathrm{S}_{-2}$ decayed or disappeared or were absorbed by transfer of energy before crossing the MAR.
In the central region $\sim 35^{\circ} \mathrm{W}$, the structures have a more obvious wavelength $\sim 510 \mathrm{~km}$ and period $\sim 190$ days or westward speed of $2.7 \mathrm{~km} \mathrm{~d}^{-1}\left(\sim 3 \mathrm{~cm} \mathrm{~s}^{-1}\right)$ but progress is not necessarily steady with $\mathrm{S}_{0}$, for example, showing a half period (or $\sim 100$ day) wobble. Westwards speeds in the Western Basin are larger $\sim \times 1.5$. Eddies do not increase their spatial scale zonally in the Western Basin as their speeds increase as further eddies are generated in the Western Basin. East of $\sim 30^{\circ} \mathrm{W}$, the structures are less organized, smaller or less intense and relatively more stationary for longer periods giving an overall reduced westward speed.

\subsection{Seasonal cycle of surface chlorophyll a and SeaWiFS data in the Subtropical Front region}

Storms and the STF have been studied by direct in situ measurements (Pingree et al., 1996), hydrography and altimeter data $(P S)$ and using infrared satellite imagery (this paper). A natural extension is to examine the STF/ AC system for signatures in the visual band (e.g. using, CZCS, SeaWiFS, MERIS data). In October 1995, no clear detectable surface chlorophyll $a$ structure or signature was found for Storm 0 (CD97 data) with chlorophyll $a$ values of typically $0.1 \mathrm{mg} \mathrm{m}^{-3}$. The seasonal cycle of surface chlorophyll $a$ (based on cruise data near $34^{\circ} \mathrm{N}$ in 

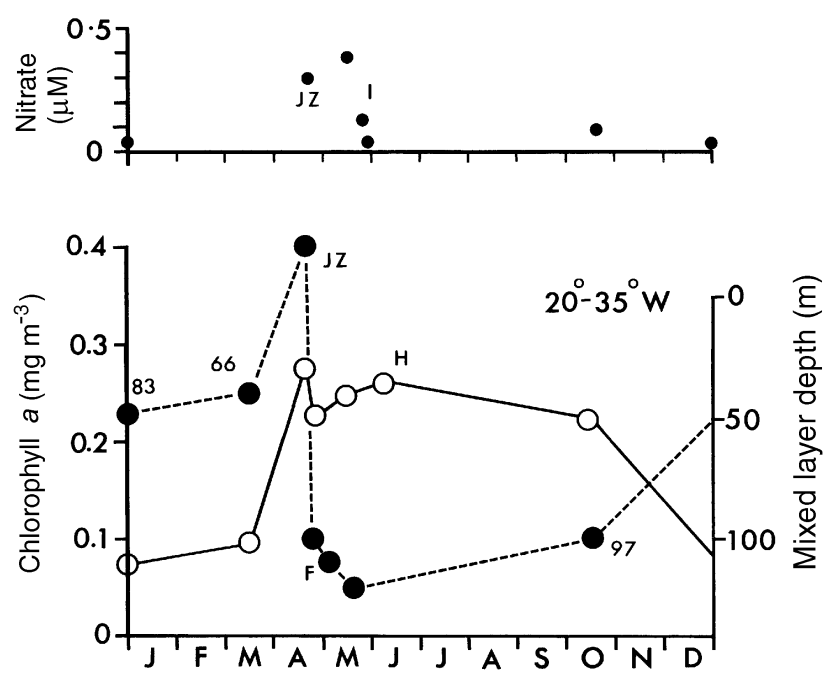

Figure 17. Seasonal cycle (month shown by letter) of surface chlorophyll $a\left(\mathrm{mg} \mathrm{m}^{-3}\right.$, dots), the base of the mixed layer or depth of upper seasonal thermocline ( $\mathrm{m}$, circles) and inorganic nitrate values (top, dots) in the Subtropical Front region $\left(\sim 33-34^{\circ} \mathrm{N}\right)$ from cruise data-CD66; CD83; CD97; H, HMS 'Hecla'; F, from Fasham et al. (1980); I, from Irwin et al. (1983); JZ, from Jochem \& Zeitzschel (1993), nitrate value near $20 \mathrm{~m}$.

the Eastern Basin, Figure 17) gives a guide to the background levels for the Subtropical Front region. Surface values are low in the summer $\left(<0.1 \mathrm{mg} \mathrm{m}^{-3}\right)$ but increase in the cooling period (see Figure 8) reaching values of $0.3 \mathrm{mg} \mathrm{m}^{-3}$ in late March (Fernández \& Pingree, 1996) when maximum values are associated with the warm side of the STF outcrop. Surface values increase in the winter (January) when deeper mixing entrains inorganic nutrients (e.g. nitrate) into the photic zone although values $>0.3 \mu \mathrm{M}$ have not been observed at the sea surface. The general increase in chlorophyll $a$ values in winter need not match the low nitrate concentration maximum as light is not limiting in the winter mixing season. The seasonal chlorophyll $a$ values are comparable to those given by Longhurst (1995) for the North Atlantic Subtropical Gyre (West) region (or NAST $(\mathrm{W})$ province) derived from the Westerlies Domain: Model 3. Future chlorophyll $a$ values in Storms and associated anticyclonic structures will be appraised for significance against these baseline values. Early summer SeaWiFS images show zonal structure associated with the northward progression of the spring bloom. The SeaWiFS structures will tend to relate to surface temperature which also has a marked north/south gradient. The $500 \mathrm{~km}$ structure in the May SeaWiFS image (Figure 18) can be identified along the STF near $\sim 33^{\circ} \mathrm{N}$ (with green protrusions near $31^{\circ} \mathrm{W}$ and $37^{\circ} \mathrm{W}$ ). These two structures could be related to altimeter sea level anomalies which propagate westward at $\sim 2.7 \mathrm{~km} \mathrm{~d}^{-1}$.

Monthly composite SeaWiFS images show a seasonal migration of the surface chlorophyll $a$ signal or levels in the region $\left(25^{\circ} \mathrm{W}-50^{\circ} \mathrm{W}, 20^{\circ} \mathrm{N}-50^{\circ} \mathrm{N}\right.$, excluding the effects of upwelling off west Africa) with a maximum southward displacement of the chlorophyll a levels in February south of $\sim 35^{\circ} \mathrm{N}$. In March, significant increases in chlorophyll $a$ gradients occur near the Subtropical
Front outcrop at $\sim 34^{\circ} \mathrm{N}$ with a spatial maximum in levels to the north $\sim 38^{\circ} \mathrm{N}$. South of $\sim 40^{\circ} \mathrm{N}$, the temporal or seasonal maximum chlorophyll $a$ levels occur in the January to April period (cf. Figure 17) but the winter maximum signal does not extend south to the region $20^{\circ} \mathrm{N}-28^{\circ} \mathrm{N}$, and $>35^{\circ} \mathrm{W}$ where the surface levels remain uniformly low (spatially and temporally) in the subtropical water. The seasonal migration (in the meridional direction) of the near zonal chlorophyll $a$ levels $\left(\sim 0.3 \mathrm{mg} \mathrm{m}^{-3}\right)$ or the chlorophyll $a$ front ranges from about $32^{\circ} \mathrm{N}$ February/March to $45^{\circ} \mathrm{N}$ August and in May the chlorophyll $a$ front is near $40^{\circ} \mathrm{N}$ (Figure 18) with bloom conditions in the Bay of Biscay (Garcia-Soto \& Pingree, 1998). Since the chlorophyll $a$ front and thermal front are similarly positioned in the winter, Storms or excursion of cooler surface water to the south show elevated sea surface chlorophyll $a$ values from January to May, though the overall levels will be higher to the north. The Storm SeaWiFS signatures were most conspicuous in April but structures related to cold water features and altimeter low sea level anomalies were evident later in the year.

In the Storm 0 survey in October 1995, a Seasoar section showed increased levels of oxygen concentration $\left(5.5 \mathrm{mll}^{-1}\right)$ at the thermocline depth $\sim 85 \mathrm{~m}$ in the central region of the eddy where the deeper thermocline was domed upwards (cf. $5.1 \mathrm{mll}^{-1}$ in the exterior regions of the eddy at the same depth) but chlorophyll $a$ or fluorescence values although increased with a subsurface

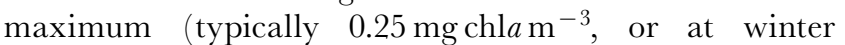
maximum levels) at the same depth were not elevated with respect to exterior values in October.

\section{CONCLUSIONS AND SUMMARY}

In the Eastern Basin of the North Atlantic Ocean, subpolar and subtropical mode waters lie alongside each other near the Subtropical Front $(\mathrm{STF})$ and $\sim 18^{\circ} \mathrm{C}$ water outcrops at the sea surface in late winter (March). The distribution of mass (STF) results in a region of maximum dynamic height gradient which defines the position for strongest eastward surface flow for the Azores Current (AC). The eastward geostrophic transport for the region is about $10 \mathrm{~Sv}$ across $30.5^{\circ} \mathrm{N}-36.5^{\circ} \mathrm{N}$ near $25^{\circ} \mathrm{W}-30^{\circ} \mathrm{W}$ but the total southward transport across $20^{\circ} \mathrm{W}-50^{\circ} \mathrm{W}$ was measured as $28 \mathrm{~Sv}$. Effectively drogued Argos buoy and ALACE float tracks are examined in conjunction with infrared satellite images and altimeter structures in the region for the structure and flow associated with the STF/ AC system and the position of the STF over a period from October 1995 to March 1997. A cyclonic eddy, or Storm 0, is followed from $33^{\circ} \mathrm{W}$ to over the Mid-Atlantic Ridge (to $\sim 41^{\circ} \mathrm{W}$ ) near a latitude of $33^{\circ} \mathrm{N}$ over a $\sim 300$ day period. Lagrangian tracks have been superposed on selected infrared images of the region for the period when the buoys were in the eddy and when they subsequently left the eddy and showed flow and structure in the STF region. Temperature sensors on the buoys define the seasonal surface temperature for the region and can be used to calibrate the imagery. Overall, the thermal imagery gives the position of the STF, whereas the altimeter shows more clearly the eddy structure. The Lagrangian data alone allows estimates of horizontal diffusion in Storm 0 and in 


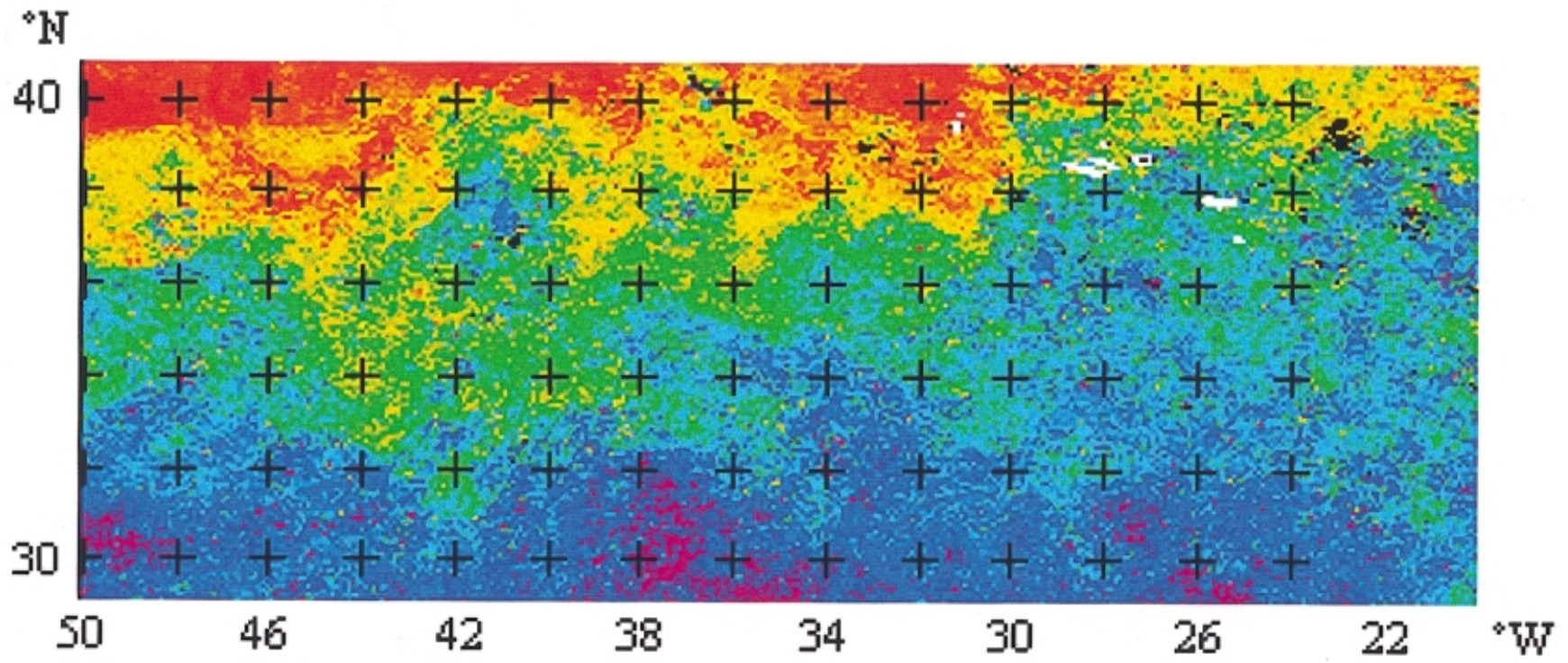

Figure 18. Composite SeaWiFS image for May 1998 with a relative chorophyll $a$ colour scale (approximately 0.04 (blue/purple near $\left.\sim 30^{\circ} \mathrm{N}\right)$ to $0.8\left(\mathrm{red},>40^{\circ} \mathrm{N}\right) \mathrm{mg} \mathrm{m}^{-3}$, see for example, Seabass.gsfc.nasa.gov/ $\sim$ seabam/bioopt_workshop/).

the general STF region itself. Diffusion in Storm 0 was about $\times 60$ smaller than in the STF region. The infrared imagery shows an occasional cool thermal signature for Storms south of the Subtropical Front, which has a temperature contrast near $35^{\circ} \mathrm{N}$. Warm structures adjacent to the cyclonic eddy, or to the north (near $34^{\circ} \mathrm{N}$ ), are also evident just south of the STF outcrop and these are shown to be turning anticyclonically. Warm water adjacent to the STF outcrop is moving eastward (i.e. AC) but this water can turn south and flow back westward and some is recirculating. The outcrop of the STF near $35^{\circ} \mathrm{N}$ has a temperature contrast of $\sim 1^{\circ} \mathrm{C}$ which can sometimes be followed for $\sim 3000 \mathrm{~km}$. An image is selected that shows the meandering variable structure of the STF over a zonal distance of $2000 \mathrm{~km}$ near $35^{\circ} \mathrm{N}$, the positions of two cold water features or Storms near $33^{\circ} \mathrm{N}$, separated by about $5^{\circ}$ of longitude $(\sim 460 \mathrm{~km})$ and still linked to the STF, and an anticyclonic warm water structure contained within the region between, near $34^{\circ} \mathrm{N}$. The most easterly cool Storm signature found near $25.5^{\circ} \mathrm{W}$ can be traced back to a generation position near $22.5^{\circ} \mathrm{W}$. Overall, the infrared imagery shows that the eddies are located in the warmer water south of the STF outcrop. The actual eddies themselves are far more readily resolved and followed using altimeter data and some Storms can have altimeter travel curves exceeding $1500 \mathrm{~km}$ over a $\sim 600$ day period. Altimeter structure shows that early structures may coalesce and start to group more regularly near $28^{\circ} \mathrm{W}$. In the region near $32.5^{\circ} \mathrm{N} 35^{\circ} \mathrm{W}$, current meter moorings and altimeter signatures (see Figure 15) show that regular Storms are separated by $510 \mathrm{~km}$ and that two Storms a year passed a fixed point over a two year interval. From $28^{\circ} \mathrm{W}$, Storms will have travelled $1000 \mathrm{~km}$ and be about one year old when they reach the MAR (near $33^{\circ} \mathrm{N}$ ). Surface measurements showing the seasonal cycle of chlorophyll $a$ in the STF region are summarized and structure, seasonality and Storm signatures in SeaWiFS data are examined.

An extensive archive of AVHRR enhanced images was kindly supplied by the Satellite Receiving Station at University of
Dundee. Image processing of selected AVHRR and SeaWiFS data was undertaken at the Remote Sensing Unit at the Plymouth Marine Laboratory. Altimeter data and products were received from AVISO, CLS and European Space Agency (grant A02.UK121). Part of this study was carried with the support of CANIGO (MAST-III Programme), a UK WOCE capital grant and the Procurement Executive, Ministry of Defence.

\section{REFERENCES}

AVISO/Altimetry, 1996. AVISO CD ROM users manual for merged TOPEX/POSEIDON products, AVI-NT-02-100, Edition 3.0., Collecte Localisation Satellites.

Carslaw, H.S. \& Jaeger, J.C., 1959. Conduction of heat in solids, 2nd ed. Oxford University Press.

Cipollini, P., Cromwell, D., Jones, M.S., Quartly, G.D. \& Challenor, P.G., 1997. Concurrent altimeter and infrared observations of Rossby wave propagation near $34^{\circ} \mathrm{N}$ in the northeast Atlantic. Geophysical Research Letters, 24, 889-892.

Davis, R.E., Webb, D.C., Regier, L.A. \& Dufour, J., 1992. The Autonomous Lagrangian Circulation Explorer (ALACE). Journal of Atmospheric and Oceanic Technology, 9, 264-285.

Dewar, W.K., 1986. Mixed layers in Gulf Stream Rings. Dynamics of Atmospheres and Oceans, 10, 1-29.

Fasham, M.J.R., Platt, T., Irwin, B. \& Jones, K., 1985. Factors affecting the spatial pattern of the deep chlorophyll maximum in the region of the Azores Front. Progress in Oceanography, 14, 129-165.

Fernández, E. \& Pingree R.D., 1996. Coupling between physical and biological fields in the North Atlantic Subtropical Front southeast of the Azores. Deep-Sea Research I, 43, 1369-1393.

Flierl, G.R., 1981. Particle motion in large-amplitude wave fields. Geophysical and Astrophysical Fluid Dynamics, 18, 39-74.

Garcia-Soto, G. \& Pingree, R.D., 1998. Late Autumn distribution and seasonality of chlorophyll- $a$ at the shelfbreak/slope region of the Armorican and Celtic Shelf. Fournal of the Marine Biological Association of the United Kingdom, 78, $17-33$.

Gould, W.J., 1985. Physical oceanography of the Azores Front. Progress in Oceanography, 14, 167-190.

Halliwell, G.R. \& Cornillon, P., 1989. Large-scale SST anomalies associated with subtropical fronts in the western North Atlantic during FASINEX. Fournal of Marine Research, 47, 757-775. 
Hernández-Guerra, L. \& Nykjaer, L., 1997. Sea surface temperature variability off northwest Africa: 1981-1989. International Fournal of Remote Sensing, 18, 2359-2358.

Holligan, P.M., Aarup, T. \& Groom, S.B., 1989. The North Sea: Satellite Colour Atlas. Continental Shelf Research, 9, 667-765.

Irwin, B., Platt, T., Lindley, P., Fasham, M.J. \& Jones, K., 1983. Phytoplankton productivity in the vicinity of a front S.W. of the Azores during May 1981. Canadian Data Report of Fisheries and Aquatic Sciences, no. 400.

Jochem, F.J. \& Zeitzschel, B., 1993. Productivity regime and phytoplankton size structure in the tropical and subtropical North Atlantic in Spring 1989. Deep-Sea Research II, 40, 495-519.

Käse, R.H. \& Krauss, W., 1996. The Gulf Stream, the North Atlantic Current, and the origin of the Azores Current. In The warmwatersphere of the North Atlantic Ocean (ed. W. Krauss), pp. 291-331. Stuttgart: Gebrüder Borntraeger.

Kielmann, J. \& Käse, R.H., 1987. Numerical modelling and eddy formation in the Azores Current frontal zone. Fournal of Physical Oceanography, 17, 529-541.

Klein, B. \& Siedler, G., 1989. On the origin of the Azores Current. Fournal of Geophysical Research, 84, 6159-6168.

Le Grand, P., 1998. An inverse modeling estimate of the geoid height in the North Atlantic. CERSAT News, 9, 1-2.

Le Traon, P.Y. \& De Mey, P., 1994. The eddy field associated with the Azores Front east of the Mid-Atlantic Ridge as observed by the Geosat altimeter. Fournal of Geophysical Research, 99, 9907-9923.

Le Traon, P.Y., Nadal, F. \& Ducet, N., 1998. An improved mapping method of multi-satellite altimeter data. Fournal of Atmospheric and Oceanic Technology, 15, 522-534.

Levitus, S., 1982. Climatological atlas of the world ocean. Rockville, Maryland: US Department of Commerce, National Oceanic and Atmospheric Administration. [NOAA Professional Paper, no. 13.]

Levitus, S. \& Boyer, T.P., 1994. World Ocean Atlas 1994. Washington DC: National Oceanographic Data Centre.

Longhurst, A., 1995. Seasonal cycles of pelagic production and consumption. Progress in Oceanography, 36, 77-167.

Müller, T.J. \& Siedler, G., 1992. Multi-year current time series in the eastern North Atlantic Ocean. Fournal of Marine Research, 50, 63-98.

New, A.L., 1997. The ventilation of the central and eastern North Atlantic Ocean. DYNAMO Final Report, 135-180.

New, A.L., Jia, Y., Coulibaly, M. \& Dengg, J., 2000. On the role of the Azores Current in the ventilation of the North Atlantic Ocean. Progress in Oceanography, submitted.

Okubo, A., 1971. Oceanic diffusion diagrams. Deep-Sea Research, 18, 789-802.

Oliveira, P.B., Amraoui, M. \& Fiúza, A.F.G., 1996. Sea surface temperature atlas of the northeast Atlantic derived from NOAA advanced very high resolution radiometer data. MORENA Scientific and Technical Report, no. 42, 44 pp.
Pingree, R.D., 1993. Flow of surface waters to the west of the British Isles and in the Bay of Biscay. Deep-Sea Research II, 40, 369-388.

Pingree, R.D., 1994. Winter warming in the southern Bay of Biscay and Lagrangian eddy kinematic from a deep-drogued ARGOS buoy. Fournal of the Marine Biological Association of the United Kingdom, 74, 107-128.

Pingree, R.D., 1997. The eastern Subtropical Gyre (North Atlantic): flow rings recirculations structure and subduction. Fournal of the Marine Biological Association of the United Kingdom, 77, 573-624.

Pingree, R.D., 2000. Westward moving Waves or Eddies (Storms) on the Subtropical/Azores Front near $32.5^{\circ} \mathrm{N}$ ? Interpretation of the Eulerian currents and temperature records at Moorings $155\left(35.5^{\circ} \mathrm{W}\right)$ and $156\left(34.4^{\circ} \mathrm{W}\right)$. In Proceedings of the Thirty-first International Liège Colloquium on Ocean Hydrodynamics, Fournal of Marine Systems, in press.

Pingree, R.D. \& Le Cann, B., 1992. Anticyclonic Eddy X91 in the Southern Bay of Biscay, May 1991 to February 1992. Journal of Geophysical Research, 97, 14353-14367.

Pingree, R.D. \& Sinha, B., 1998. Dynamic topography (ERS-1/2 and Seatruth) of Subtropical Ring (STORM 0) in the Storm corridor $\left(32-34^{\circ} \mathrm{N}\right.$, Eastern Basin, North Atlantic Ocean). Fournal of the Marine Biological Association of the United Kingdom, 78, 351-376.

Pingree, R.D., Sinha, B., New, A.L., Waddington, I., Head, R.N. \& Nechvolodov, L.V., 1996. Will deep subtropical Ring 'Storm Physalia' cross the Mid-Atlantic Ridge and reach America? Fournal of the Marine Biological Association of the United Kingdom, 76, 553-567.

Plymouth Marine Laboratory, 1995. RRS 'Charles Darwin' Cruise 97/ 95 Report, 12 October-6 November. Plymouth Marine Laboratory.

Pollard, R.T., Griffiths M.J., Cunningham, A., Read, J.F., Perez, F.F. \& Rios, A.F., 1996. Vivaldi 1991 — a study of the formation, circulation and ventilation of eastern North Atlantic Central Water. Progress in Oceanography, 37, 167-192.

Rios, A.F., Perez, F.F. \& Fraga, F., 1992. Water masses in the upper and middle N. Atlantic Ocean east of the Azores. DeepSea Research, 39, 645-658.

SATMER, 1984. Bulletin mensuel de renseignements oceanographiques obtenus a partir de mesures satellitaires meteorologiques sur la Méditerrannée et l'Atlantique Nord-Est; Mars 1984. Lannion: Centre de Meteorologie Spatiale.

SATMER, 1983 to 1988. Bulletin mensuel de renseignements oceanographiques obtenus a partir de mesures satellitaires meteorologiques sur la Méditerrannée et l'Atlantique Nord-Est. Lannion: Centre de Meteorologie Spatiale.

Siedler, G. \& Onken, R., 1996. Eastern recirculation. In The warmwatersphere of the North Atlantic Ocean (ed. W. Krauss), pp. 339-360. Stuttgart: Gebrüder Borntraeger.

Tychensky, A., Le Traon, P.Y., Hernandez, F. \& Jourdan, D., 1998. Large structures and temporal change in the Azores Front during the SEMAPHORE experiment. Fournal of Geophysical Research, 103, 25009-25027. 